ISSN (Print): 2709-9636 | ISSN (Online): 2709-9644

Volume 2, 2021(Issue III, July to September)

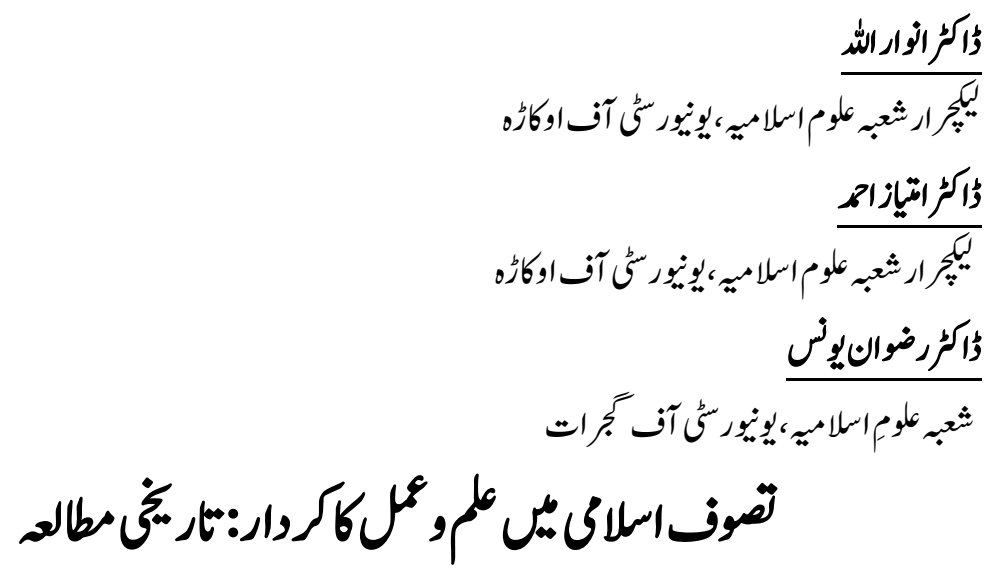

Dr. Anwarullah

Lecturer, Dept. of Islamic Studies, University of Okara.

Dr. Imtiaz Ahmed

Lecturer, Dept. of Islamic Studies, University of Okara.

Dr. Rizwan Younas

Department of Islamic Studies, University of Gujrat.

\title{
The Role of Education and Performnce in Islamic Mysticism: A Historical Study
}

A large part of this Muslim Ummah is a believer in Sufism and Sufis. The popularity of Sufism has been evident, especially in the Indian subcontinent, as it is a proven historical fact that Sufis have been the first preachers of Islam in this region. In this society, Sofia's social and spiritual services are unforgettable. In the recent past, some scholars and researchers have started calling Sufism and Sufis an anti-Islamic movement. They are mentioned in various books in Urdu and other languages. The research paper under review sheds light on the historical background of Sufism. This research paper examines the views of different scholars and explores the relationship between Sufism and Islam. This research article will guide future researchers in investigating various aspects of Islamic mysticism.

Key Words: Mysticism, Education, History, Islam, Vrdu Language. 


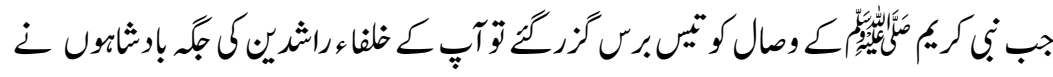

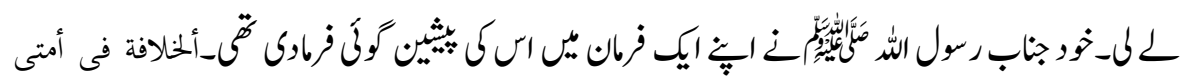

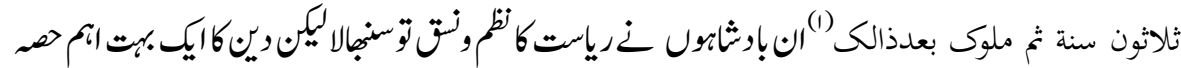

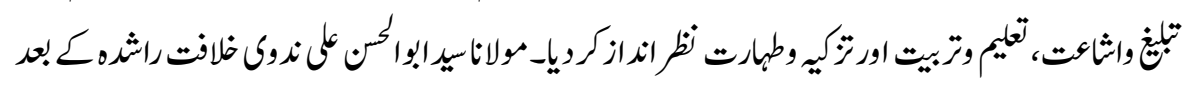

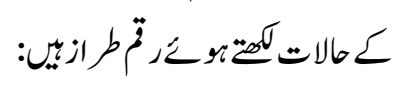

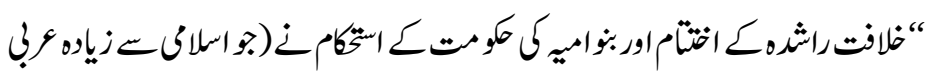

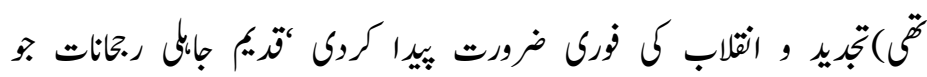

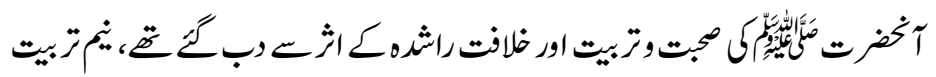

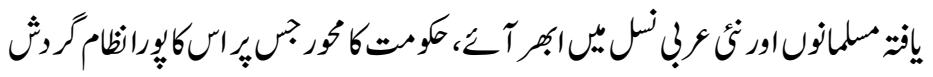

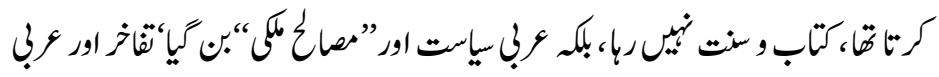

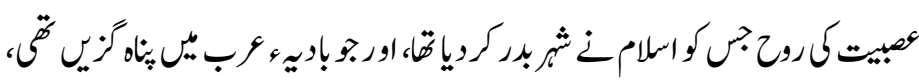

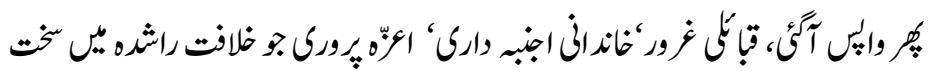

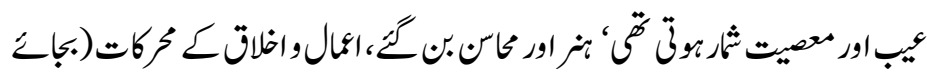

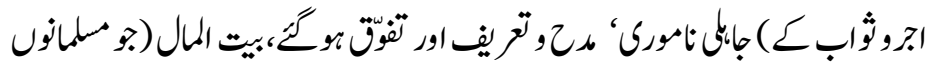

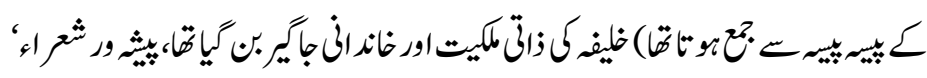

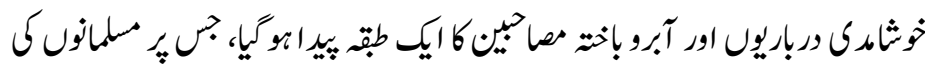

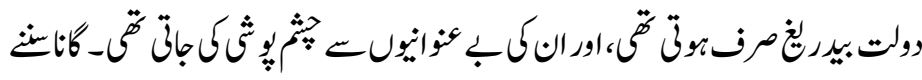

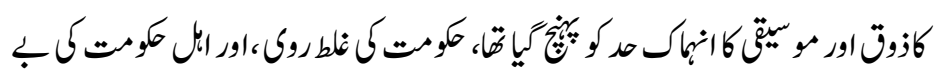

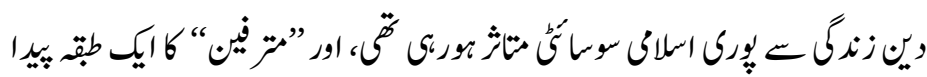

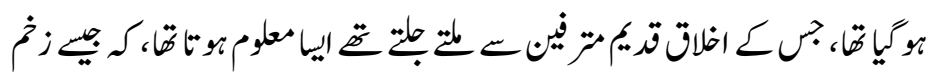

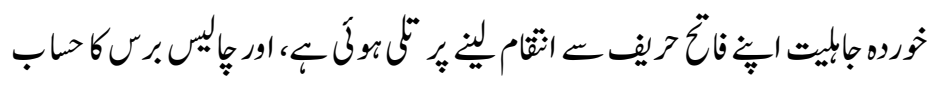

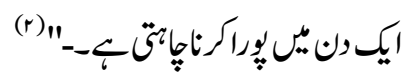


ISSN (Print): 2709-9636 | ISSN (Online): 2709-9644

Volume 2, 2021(Issue III, July to September)

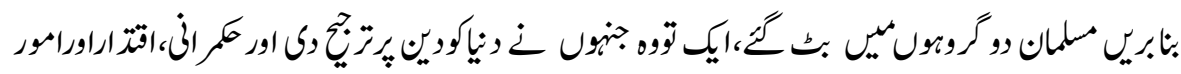

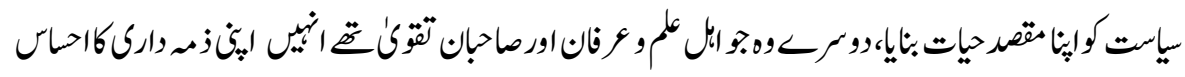

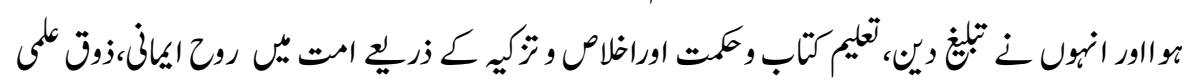

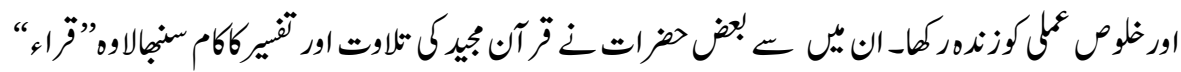

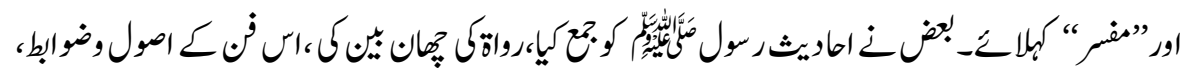

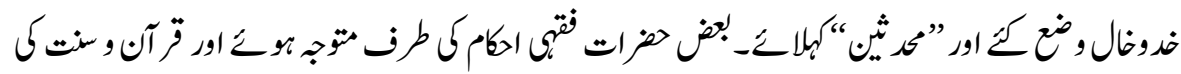

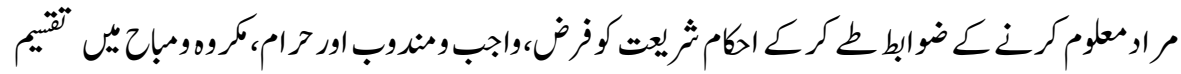

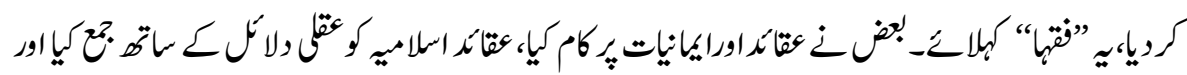

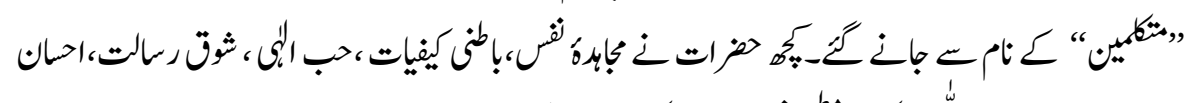

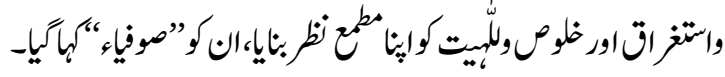

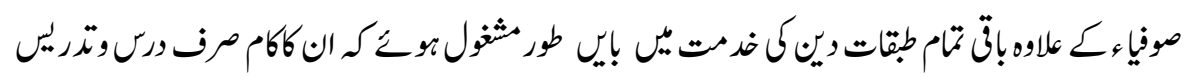

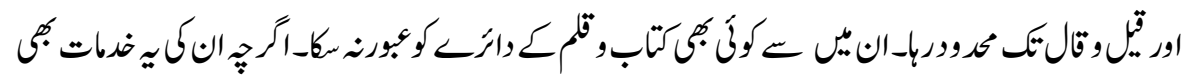

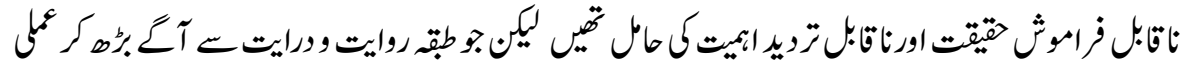

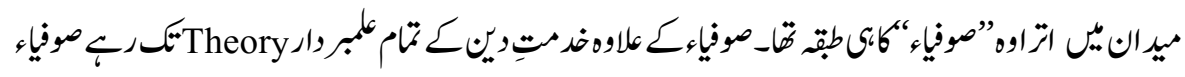
Practical centres ن صاحب

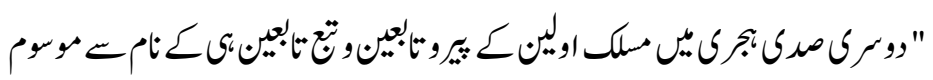

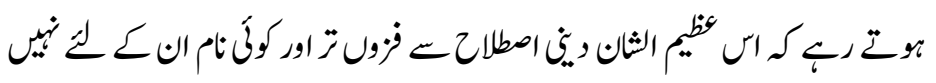

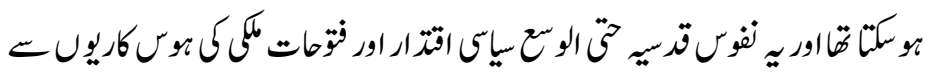

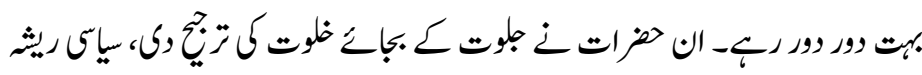

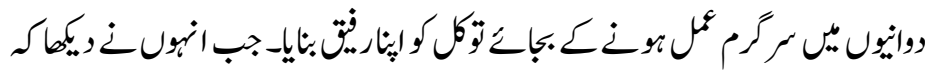

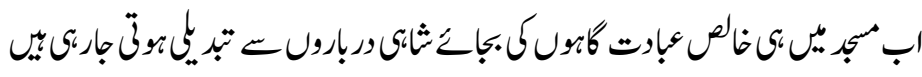

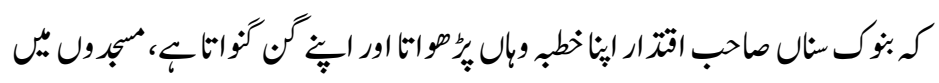


ISSN (Print): 2709-9636 | ISSN (Online): 2709-9644

Volume 2, 2021(Issue III, July to September)

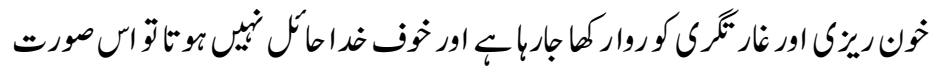

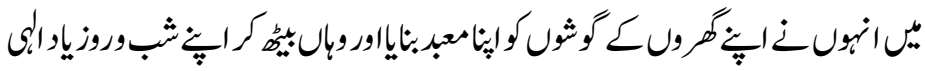

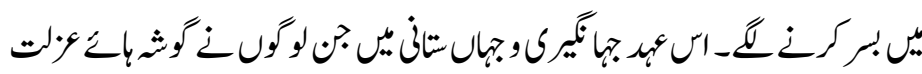

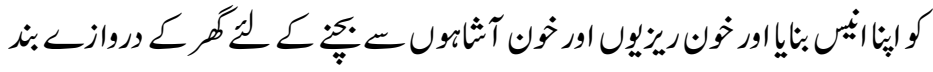

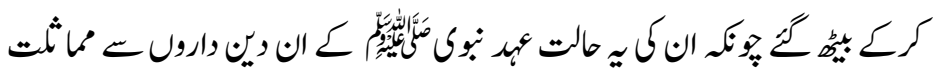

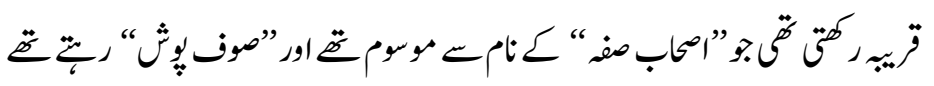

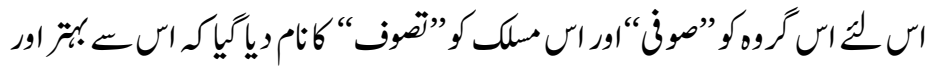

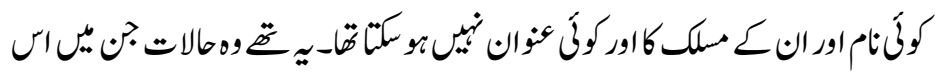

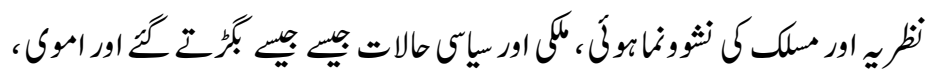

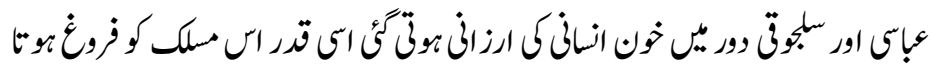

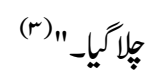

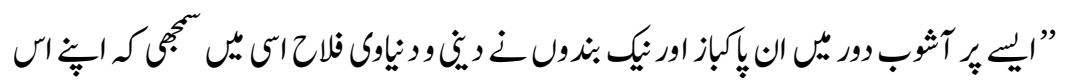

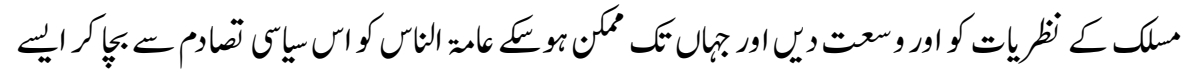

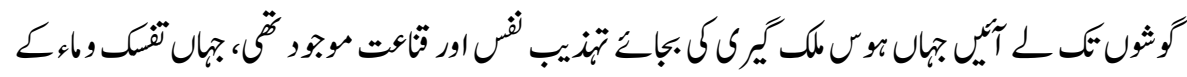

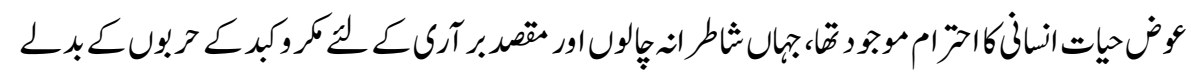

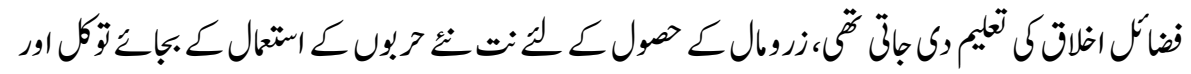

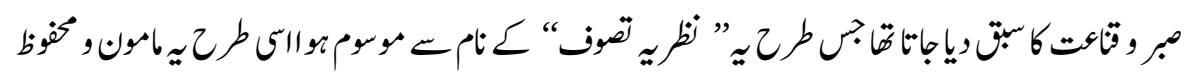

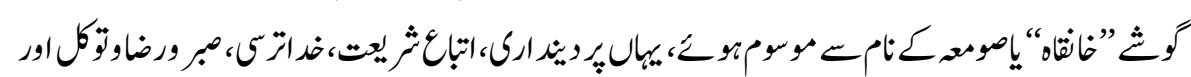

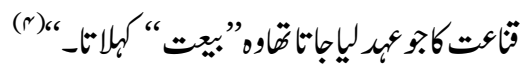

صوفن منهومومصداق

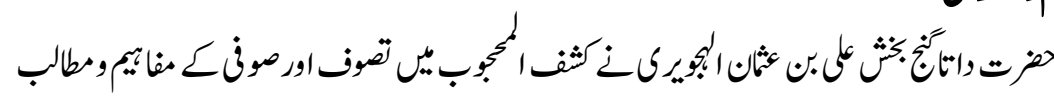

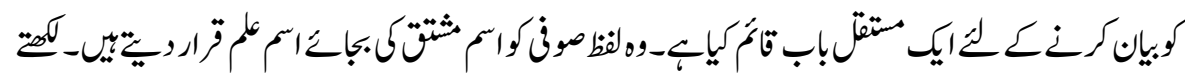


ISSN (Print): 2709-9636 | ISSN (Online): 2709-9644

Volume 2, 2021(Issue III, July to September)

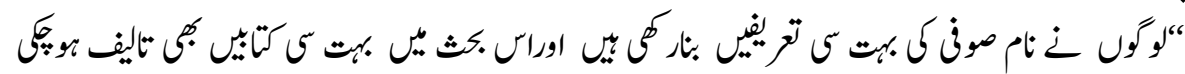

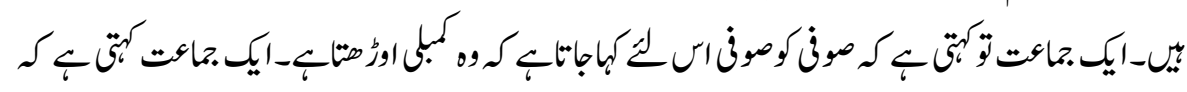

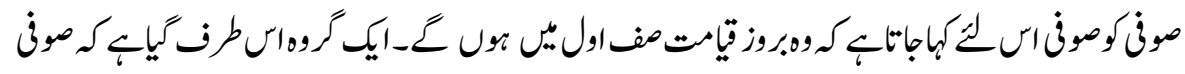

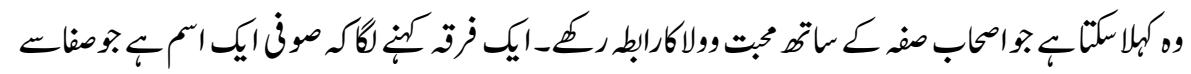

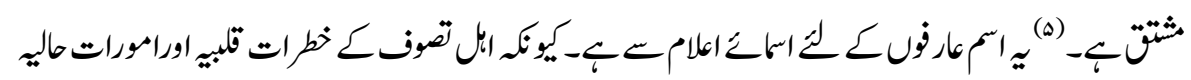

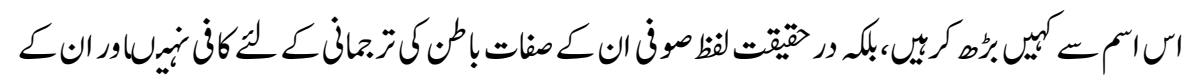

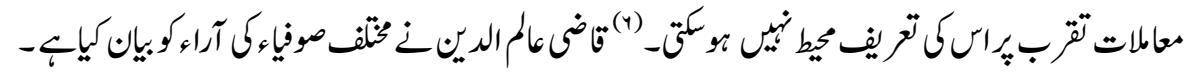
وهيولرقمر ازئ:

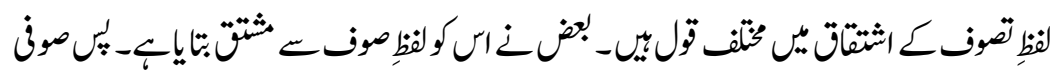

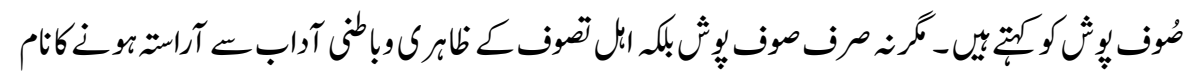

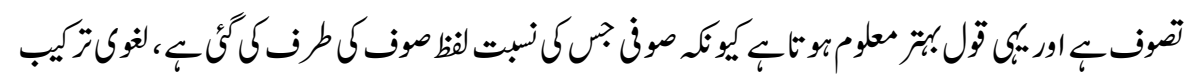

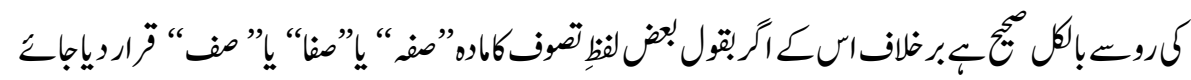

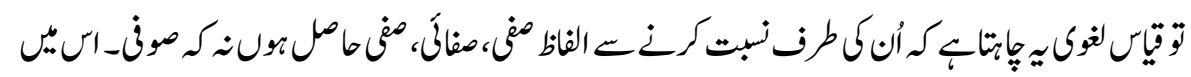

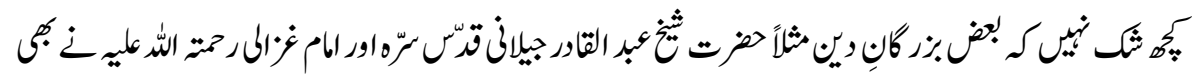

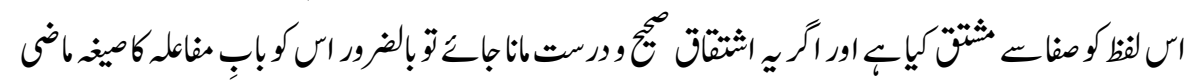

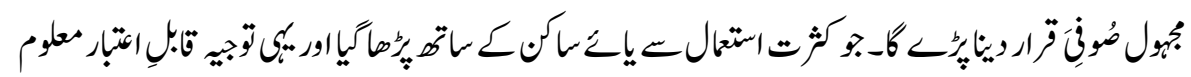

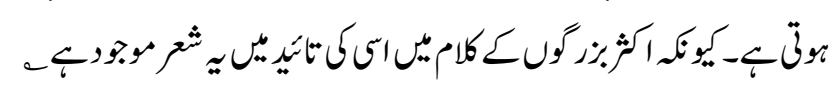

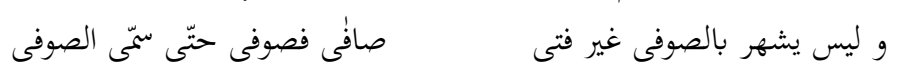

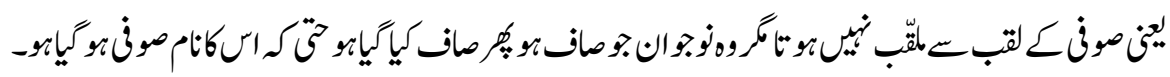

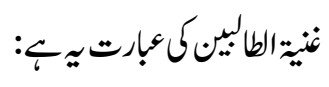

فهو فى الاصل صوفى على وزن فوعل ماخوذ من المصافات يعنى عبدا صافاه الحق عزّوجل ولهذا قيل

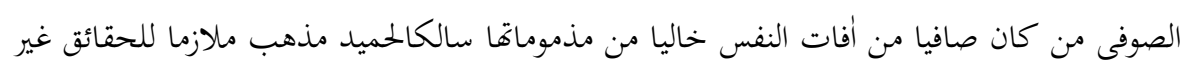
ساكن بقلبه الى احد من الخلائق 


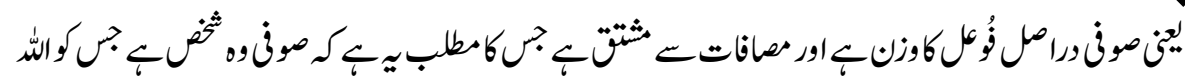

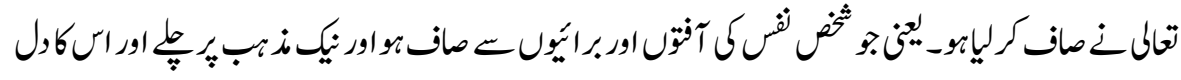

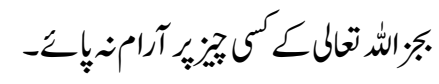

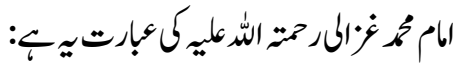

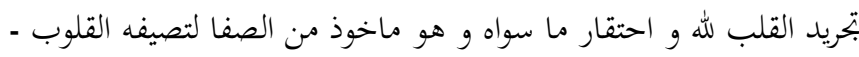

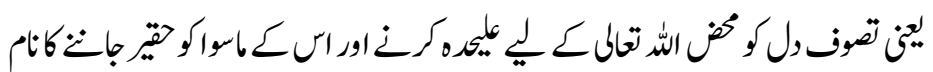

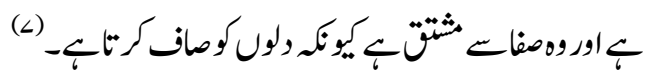

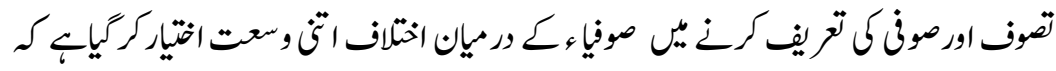

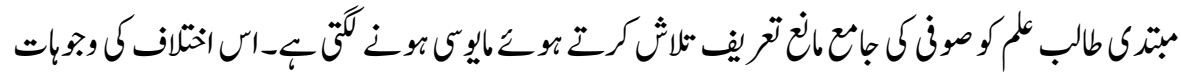

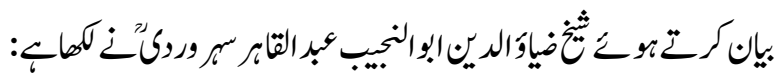

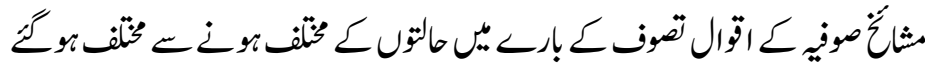

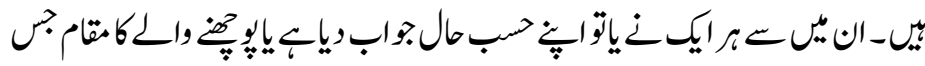

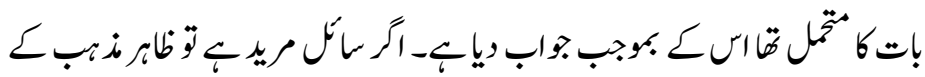

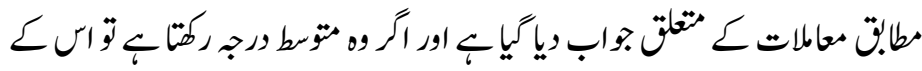

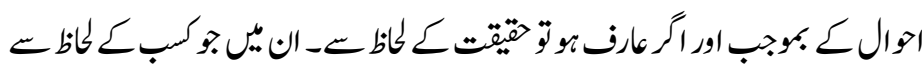

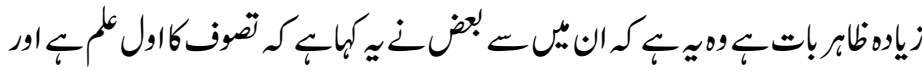

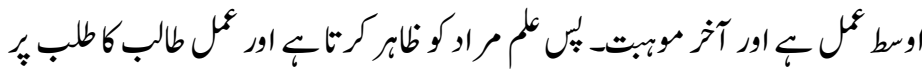

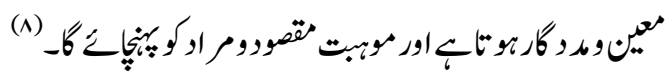

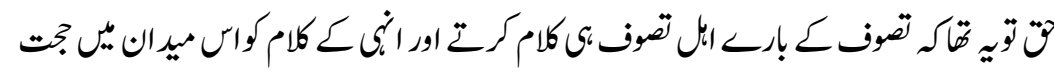

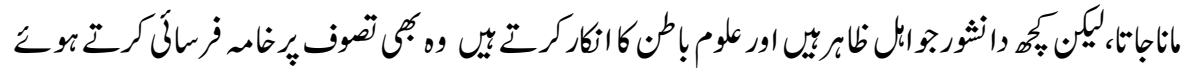

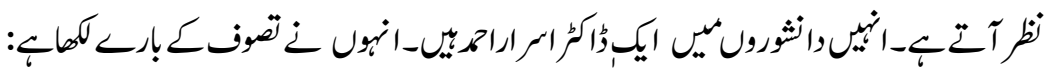

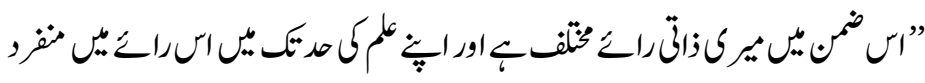

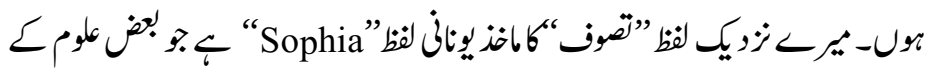


ISSN (Print): 2709-9636 | ISSN (Online): 2709-9644

Volume 2, 2021(Issue III, July to September)

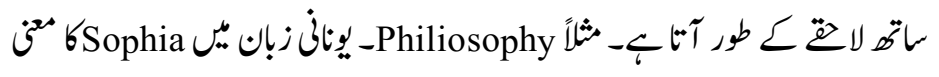

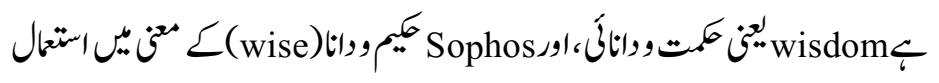

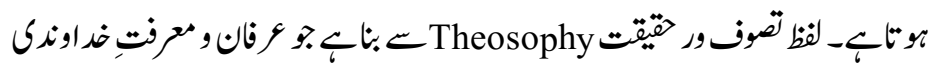

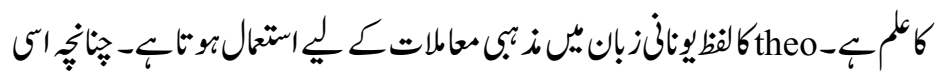

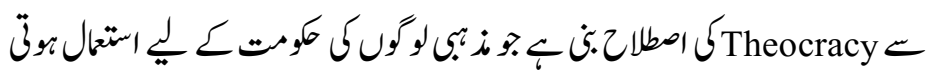

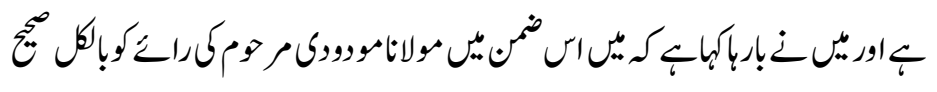

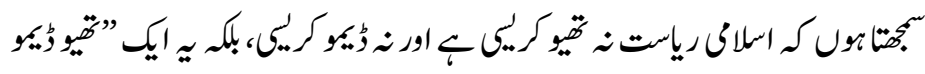

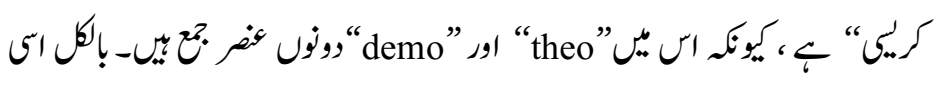

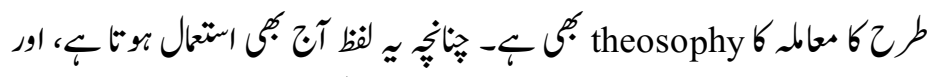

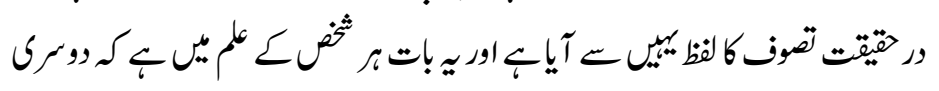

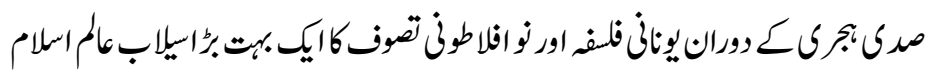

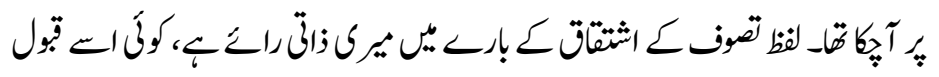

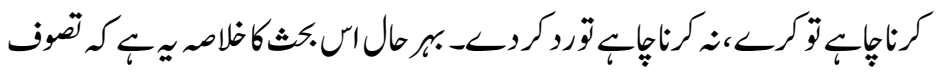

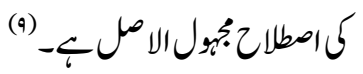

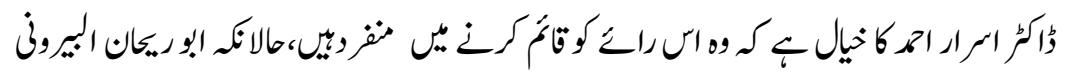

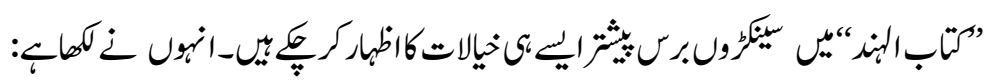

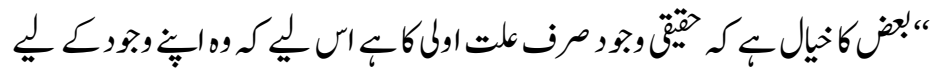

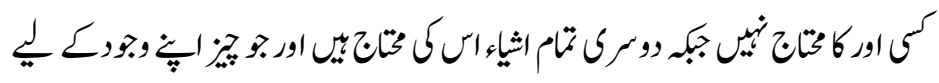

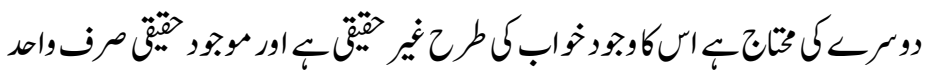

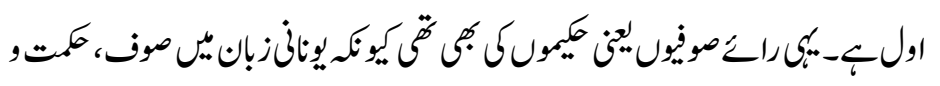

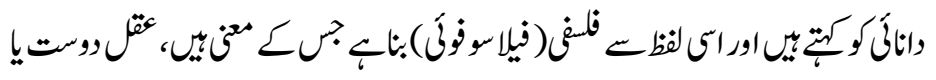

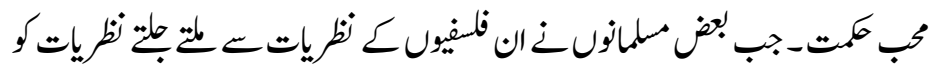

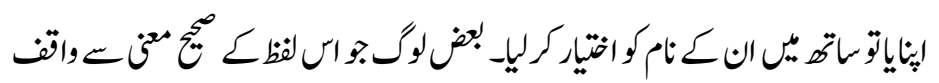


ISSN (Print): 2709-9636 | ISSN (Online): 2709-9644

Volume 2, 2021(Issue III, July to September)

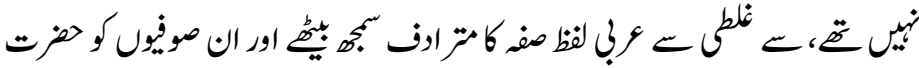

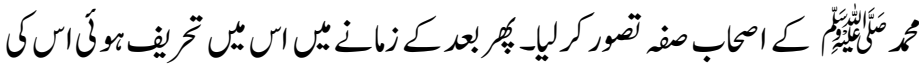

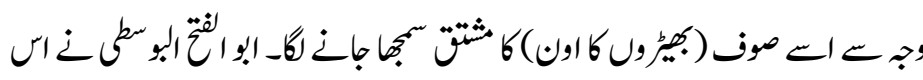

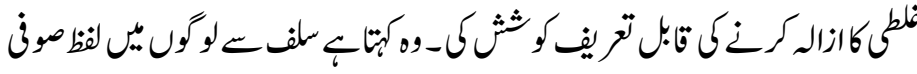

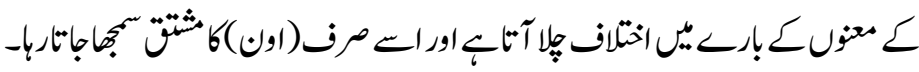

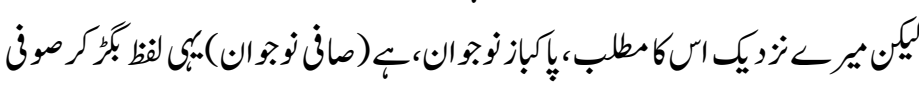

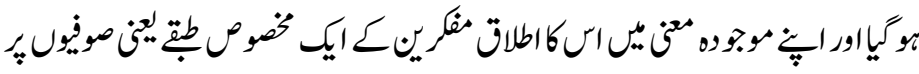

$$
\text { (1.), بون }
$$

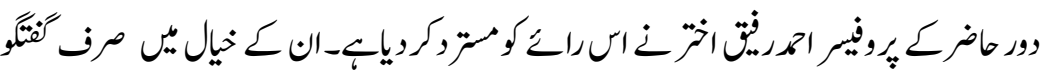

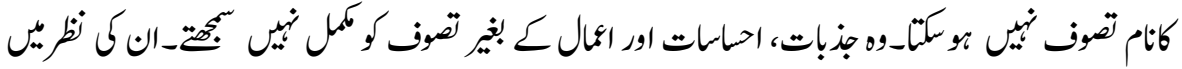

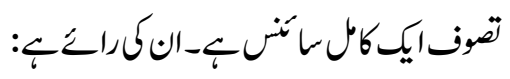

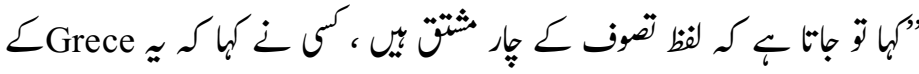

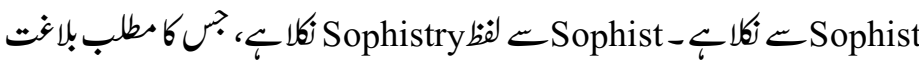

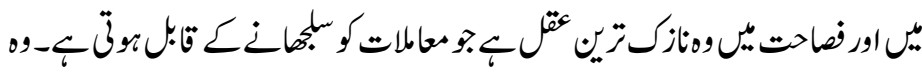

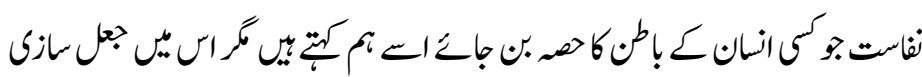

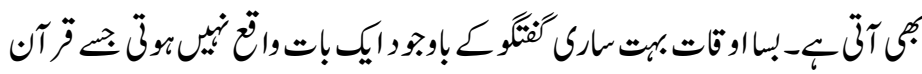

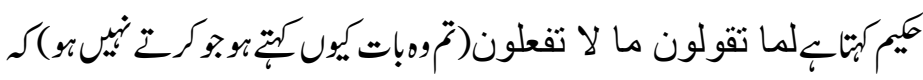

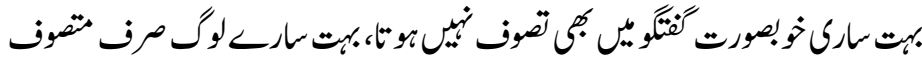

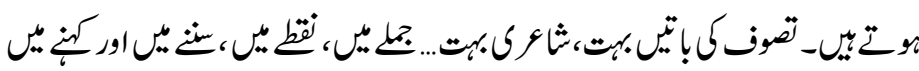

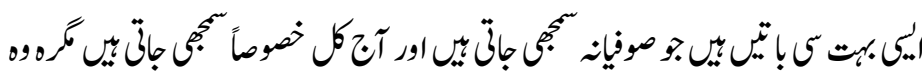

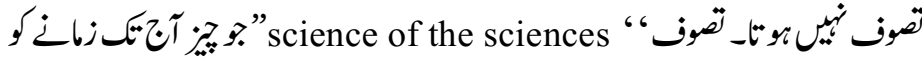

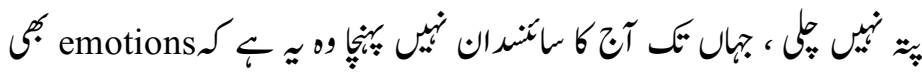

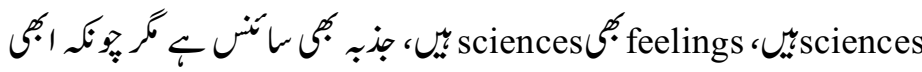




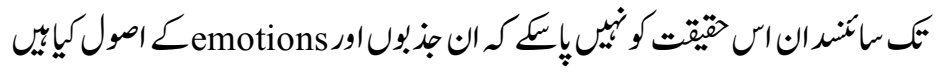

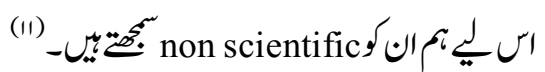

تصون ع خالثينوموانيّن

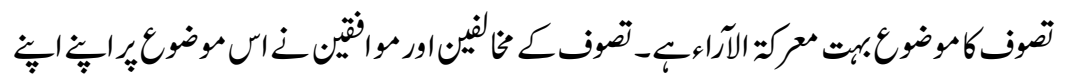

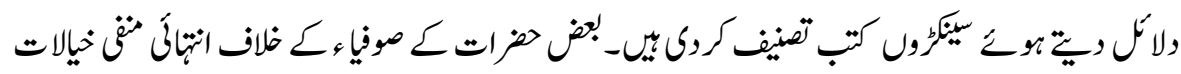

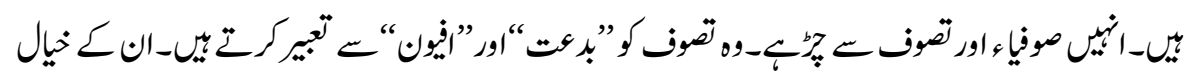

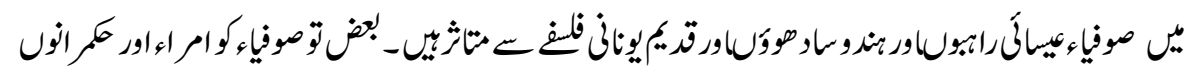

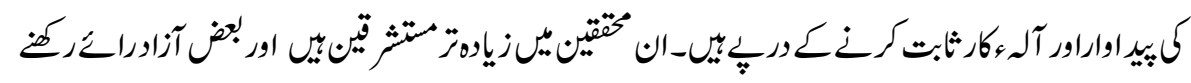

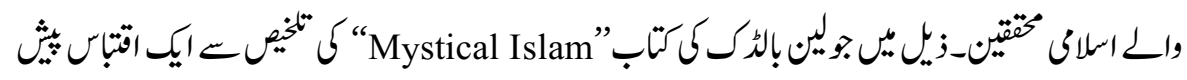

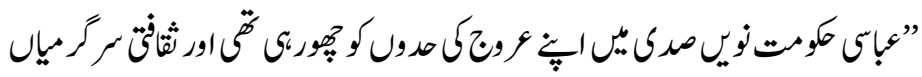

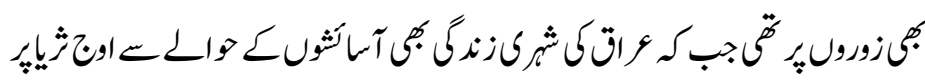

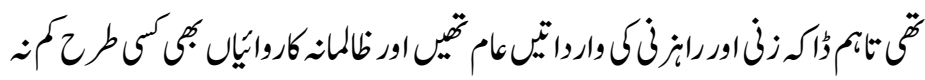

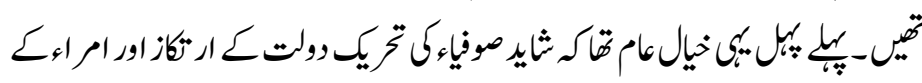

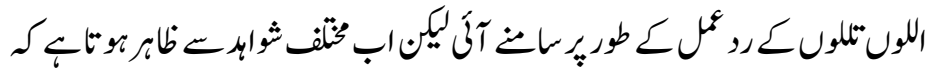

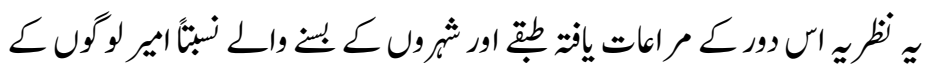

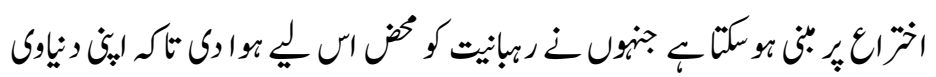

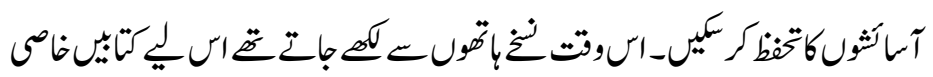

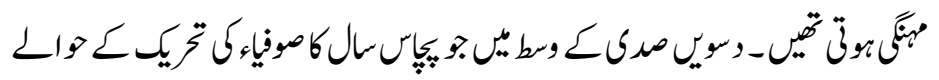

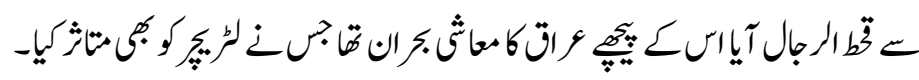

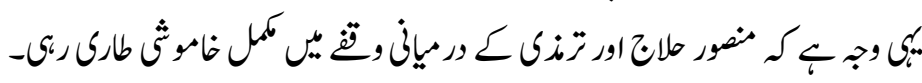

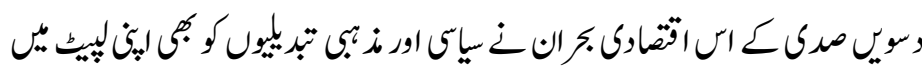
(ir)، - 
ISSN (Print): 2709-9636 | ISSN (Online): 2709-9644

Volume 2, 2021(Issue III, July to September)

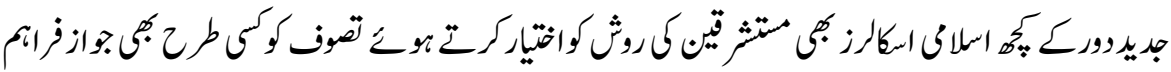

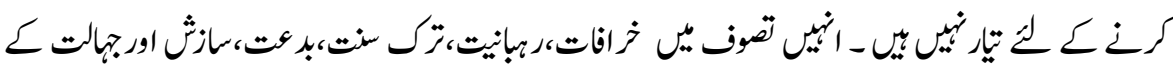

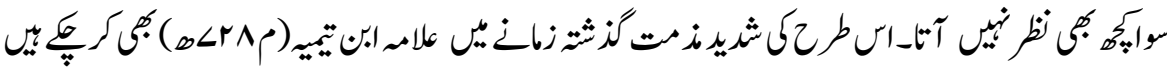

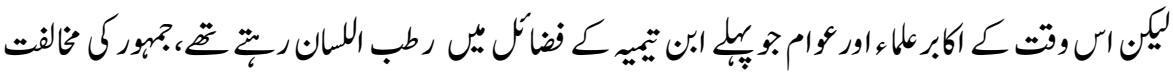

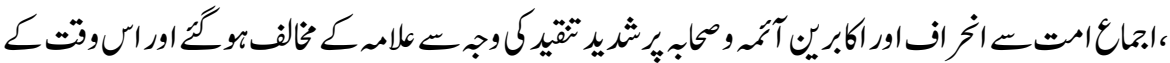

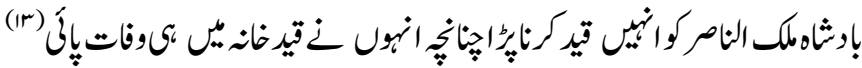

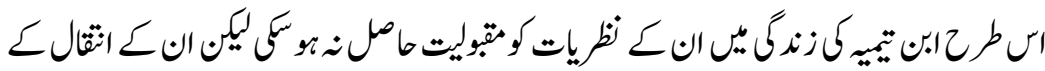

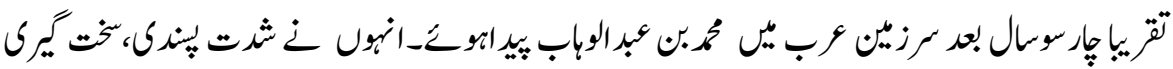

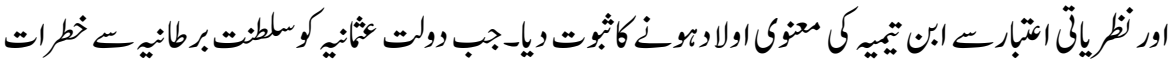

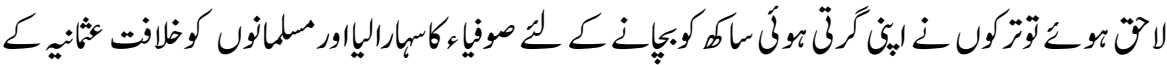

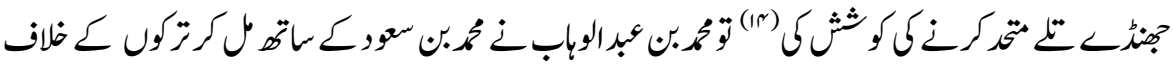

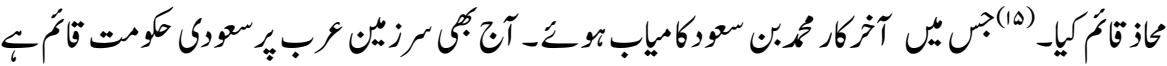

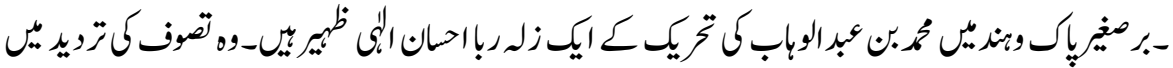

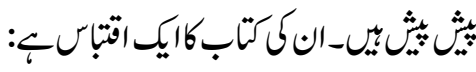

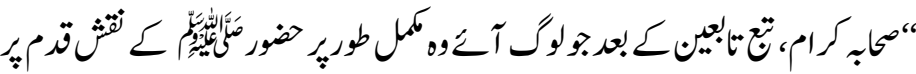

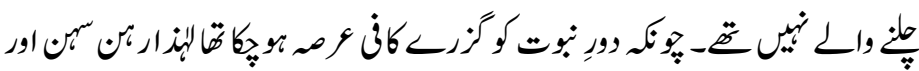

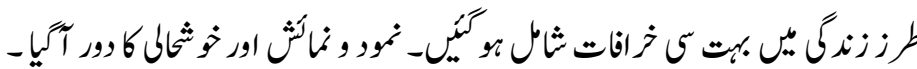

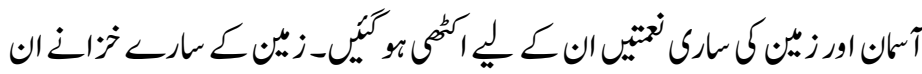

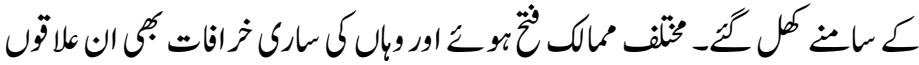

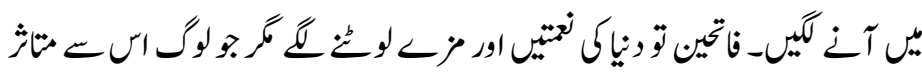

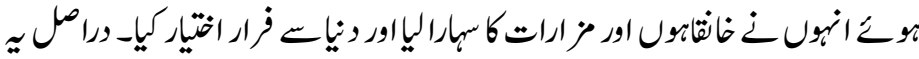

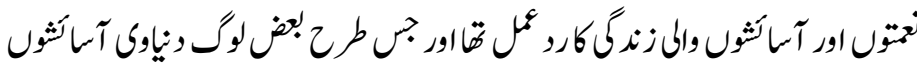

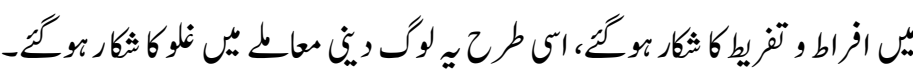


ISSN (Print): 2709-9636 | ISSN (Online): 2709-9644

Volume 2, 2021(Issue III, July to September)

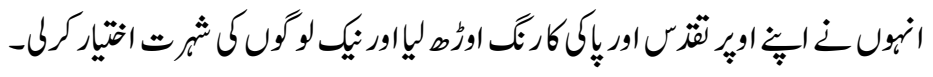

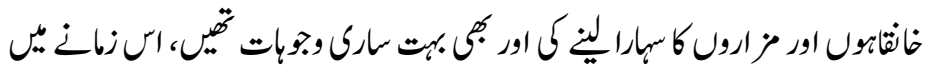

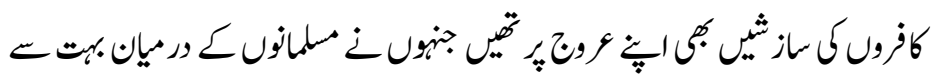

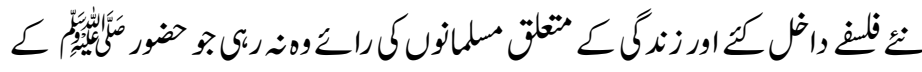

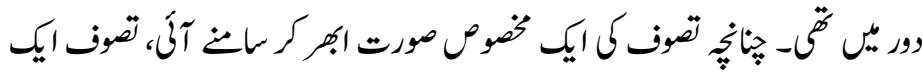

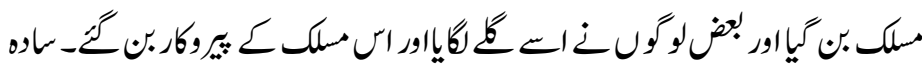

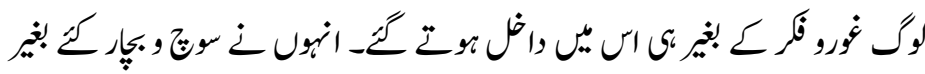

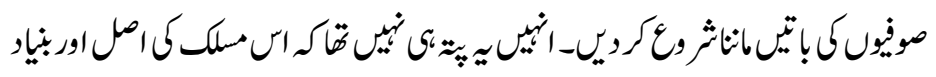

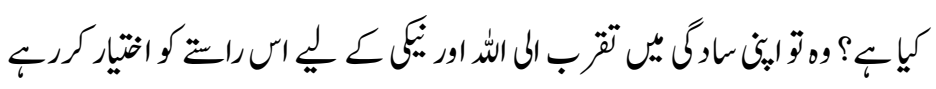

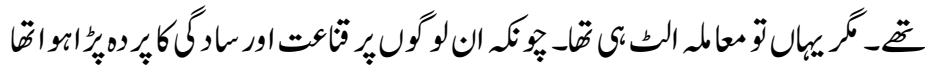

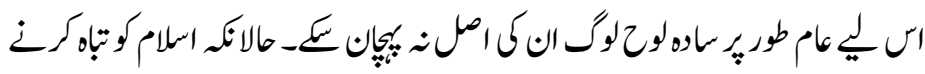

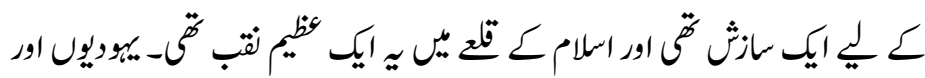

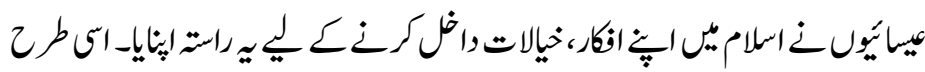

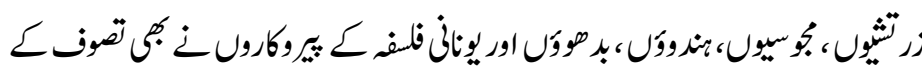

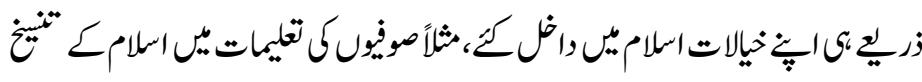

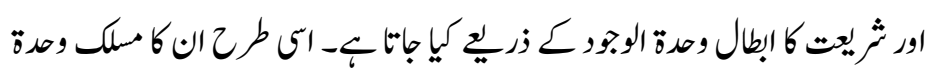

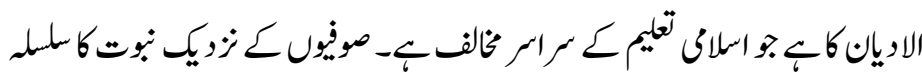

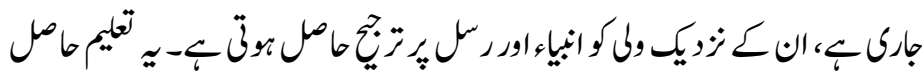

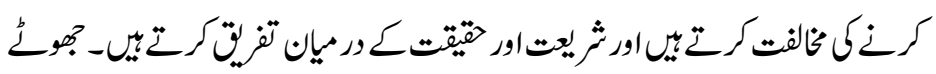

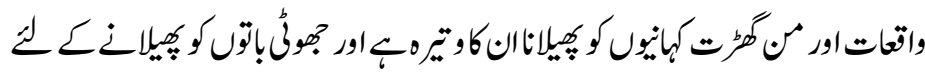

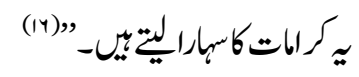

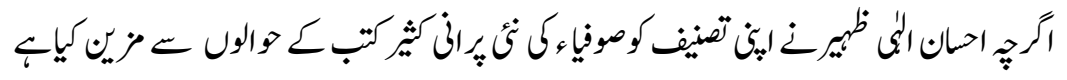

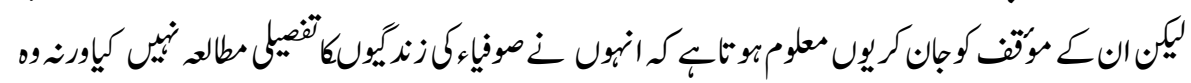


ISSN (Print): 2709-9636 | ISSN (Online): 2709-9644

Volume 2, 2021(Issue III, July to September)

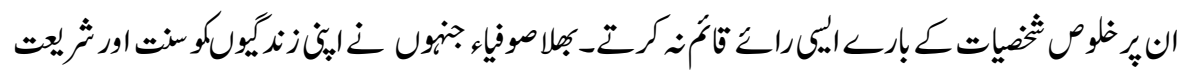

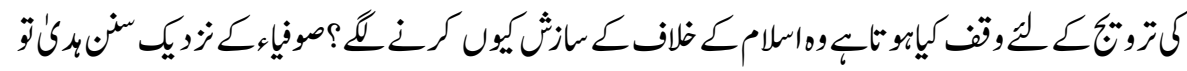

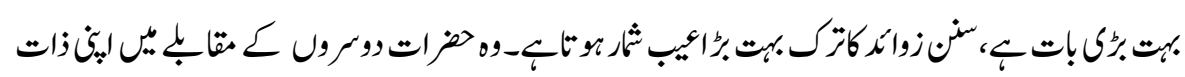

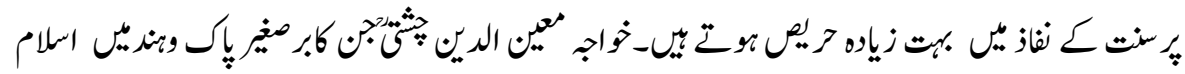

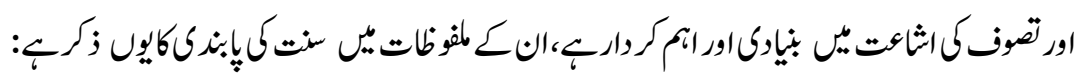

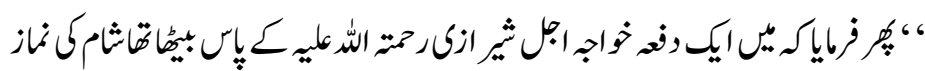

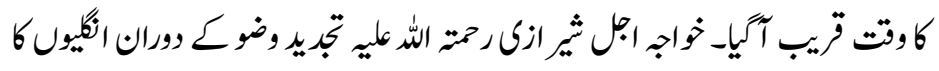

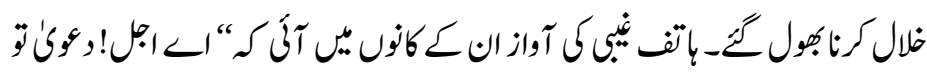

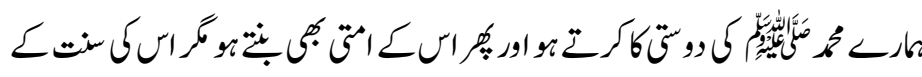

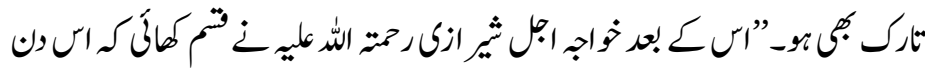

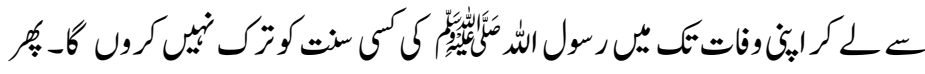

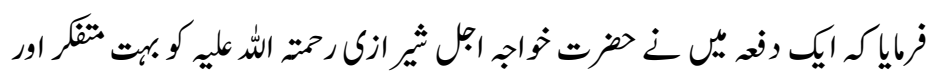

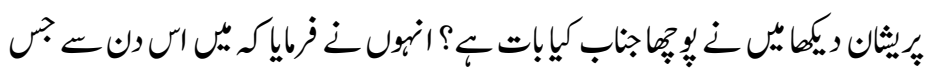

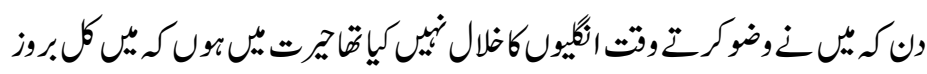

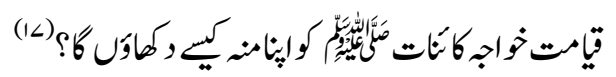

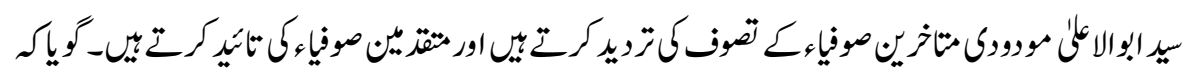

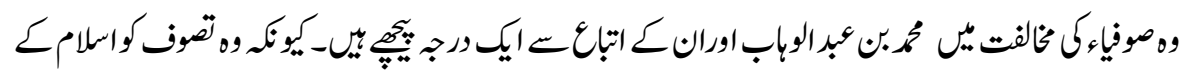

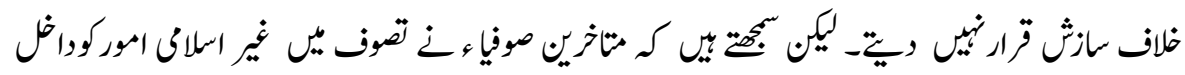

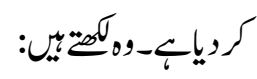

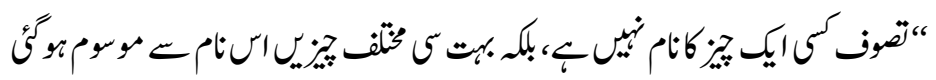

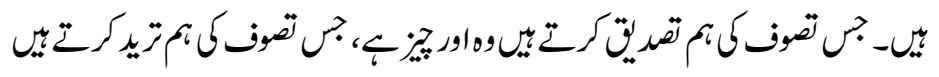

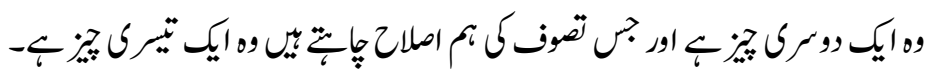

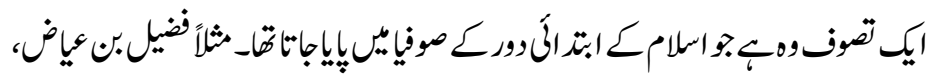




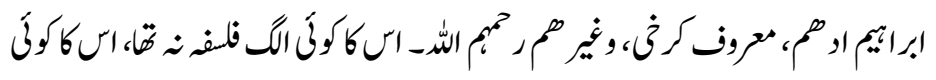

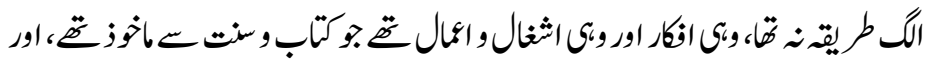

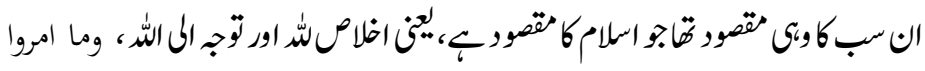

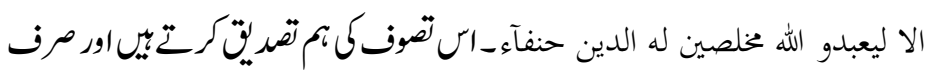

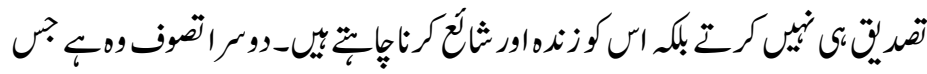

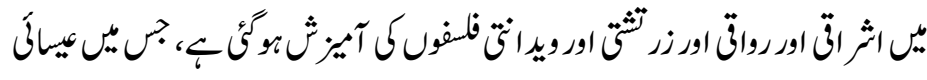

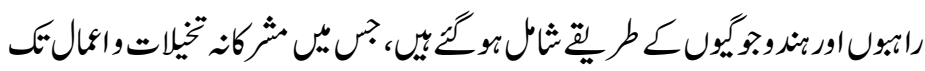

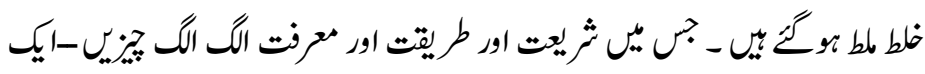

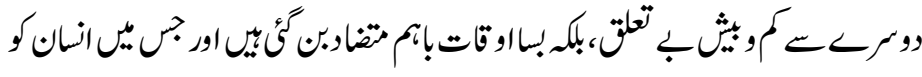

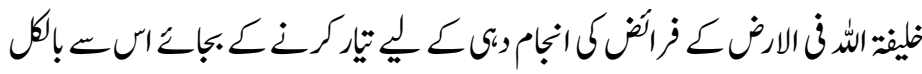

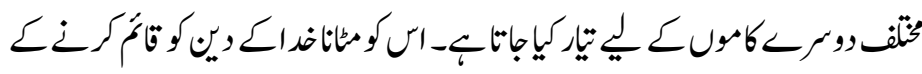

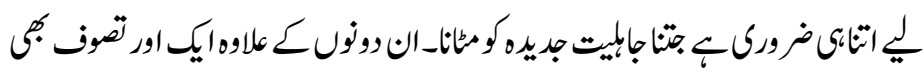

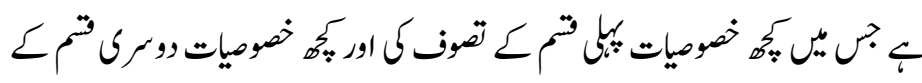

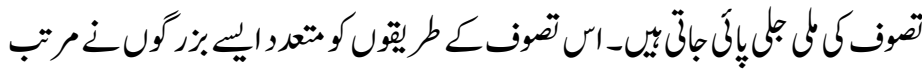

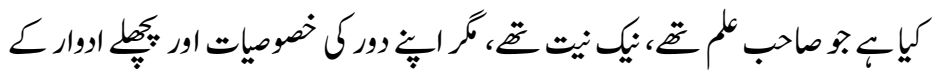

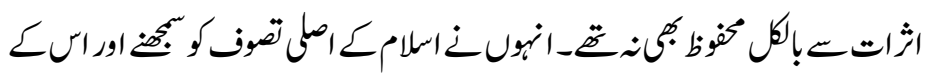

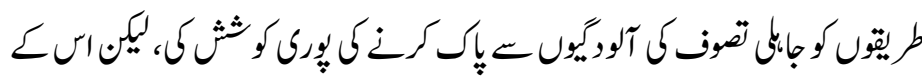

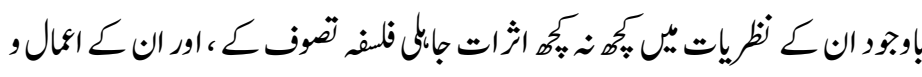

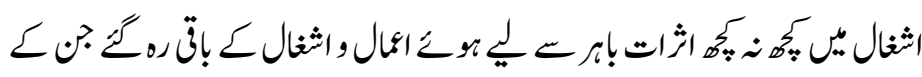

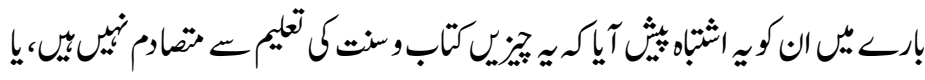

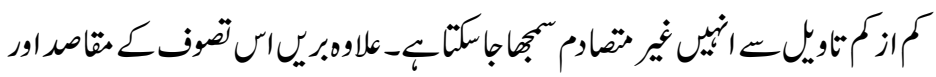

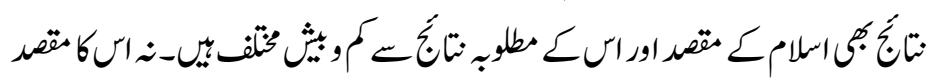

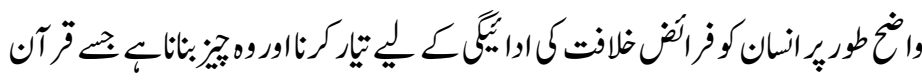


ISSN (Print): 2709-9636 | ISSN (Online): 2709-9644

Volume 2, 2021(Issue III, July to September)

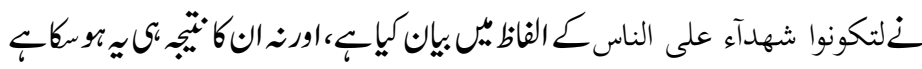

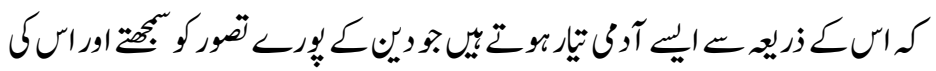

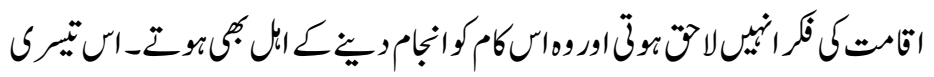

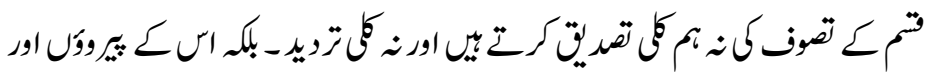

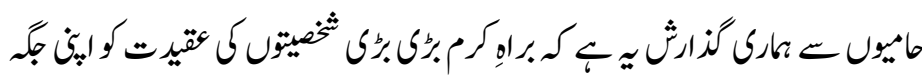

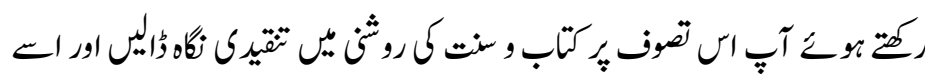

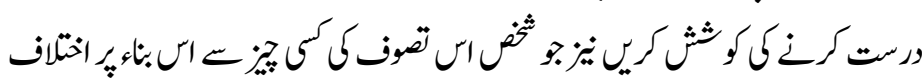

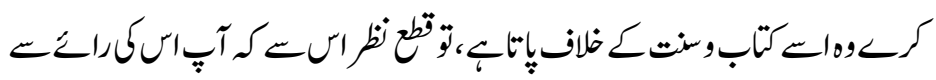

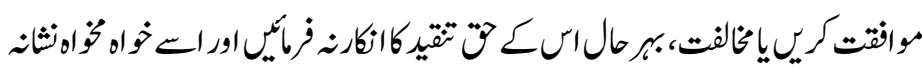

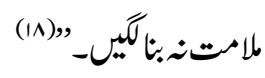

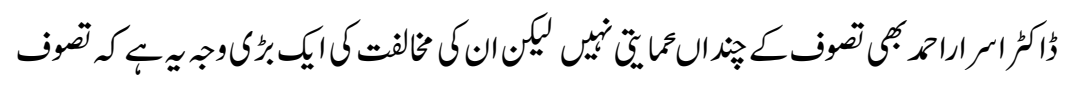

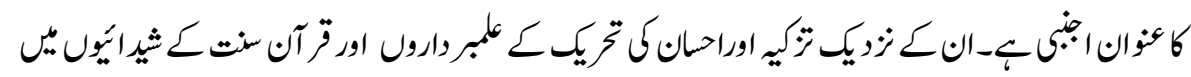

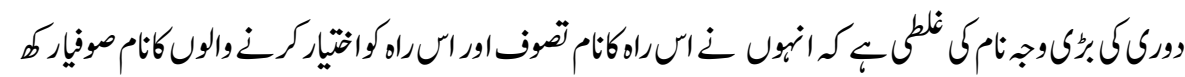

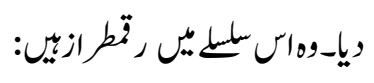

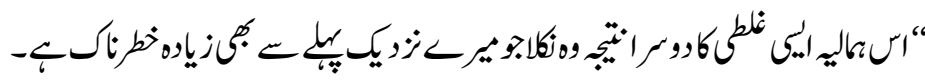

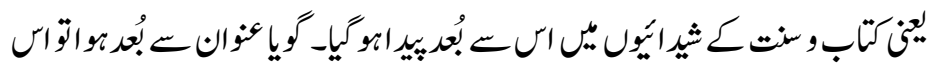

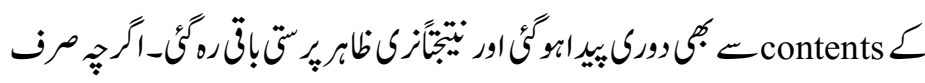

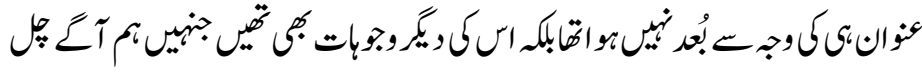

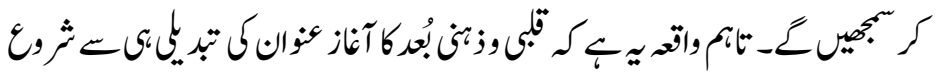

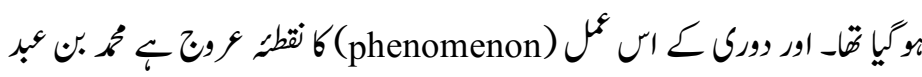

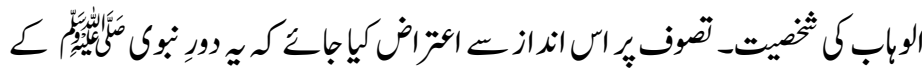

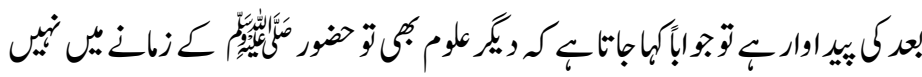

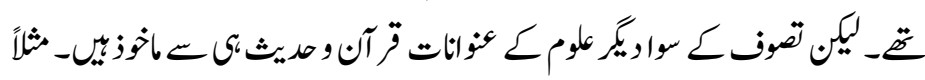




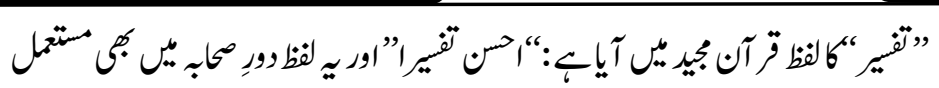

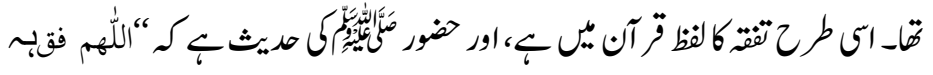

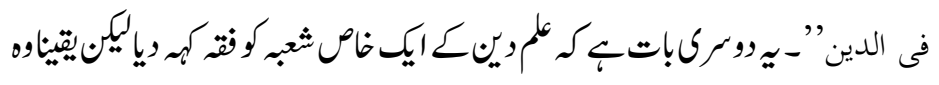

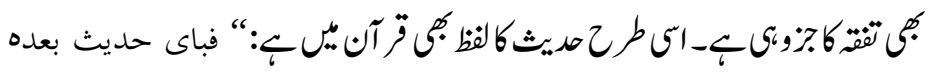

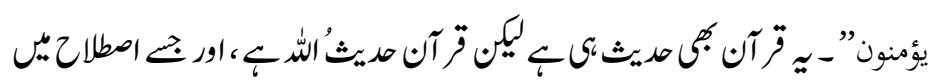

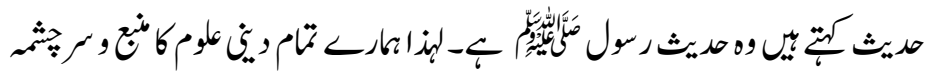

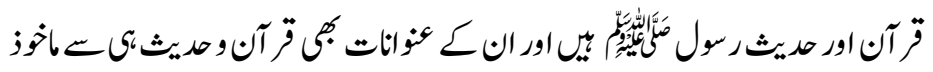

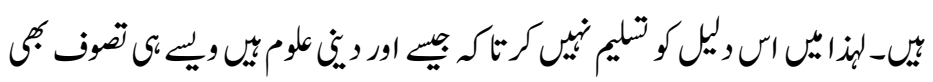

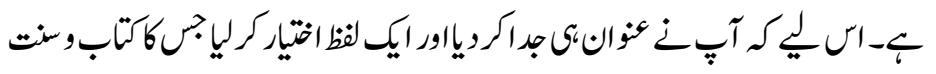

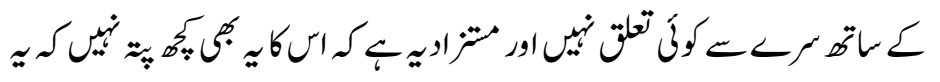

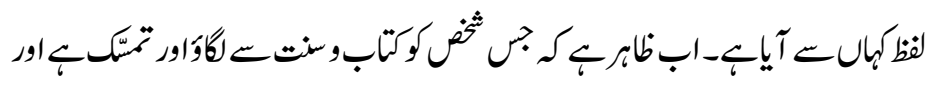

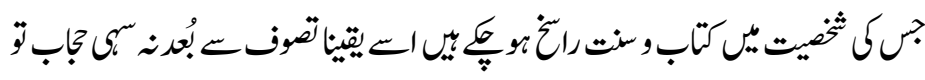

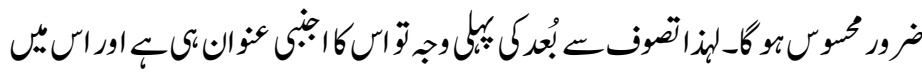

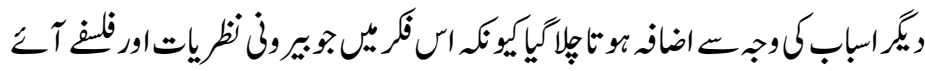

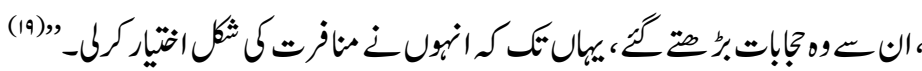

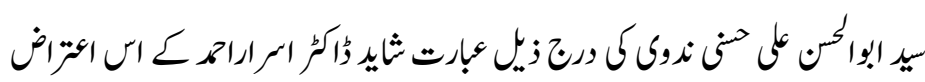

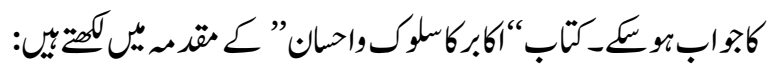

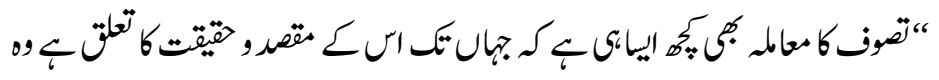

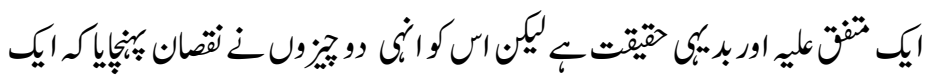

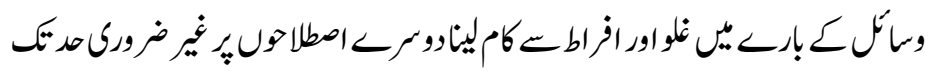

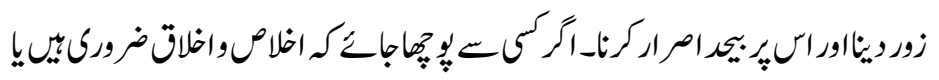

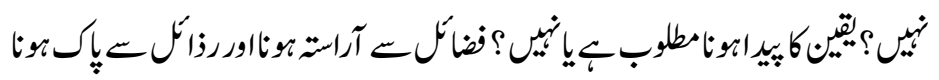

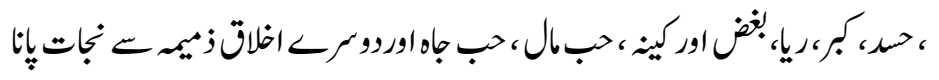




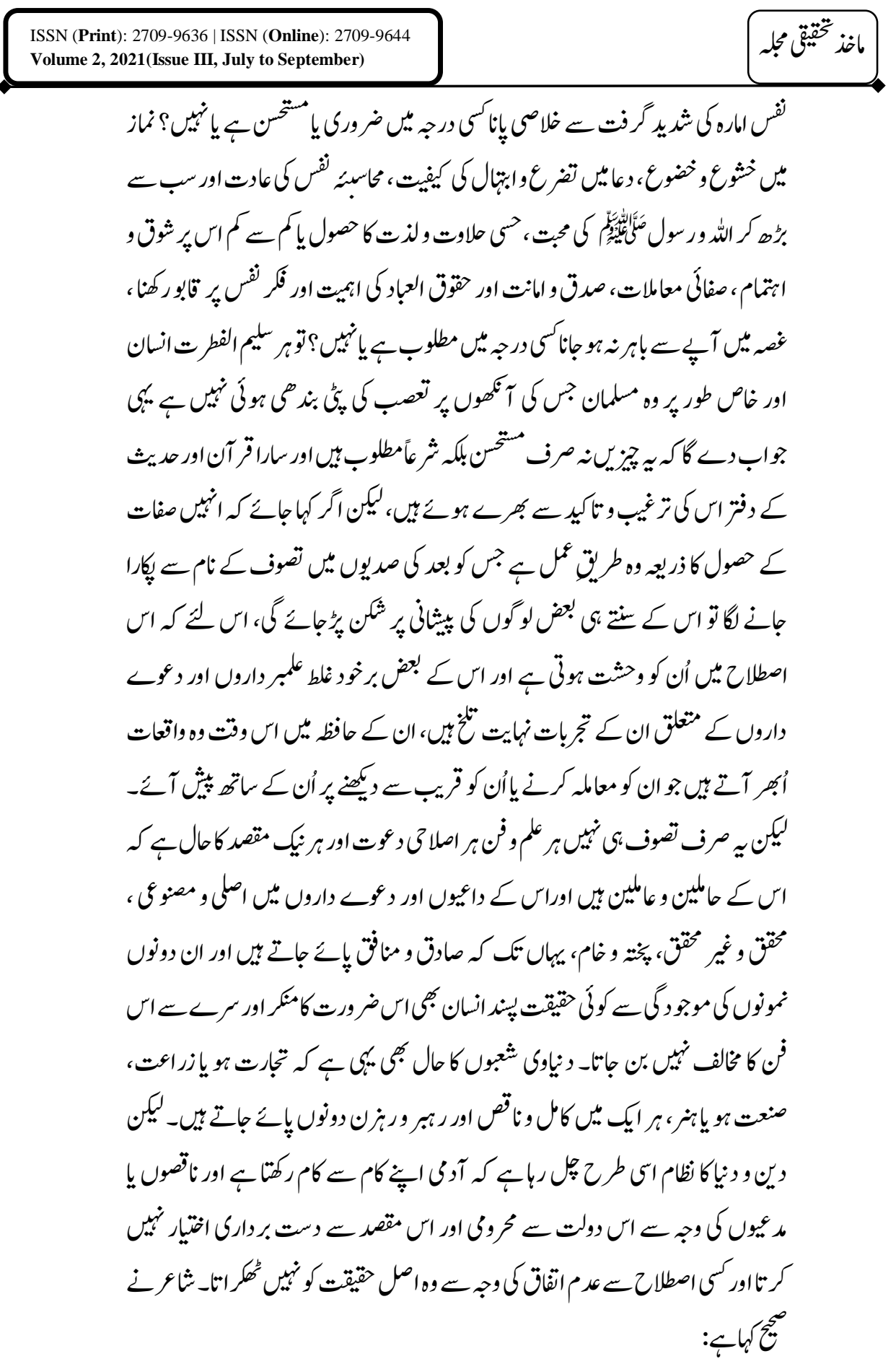




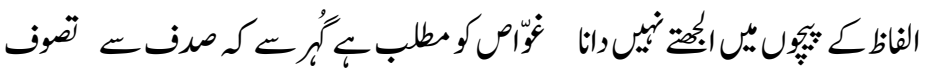

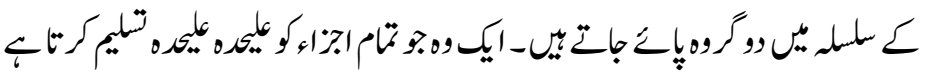

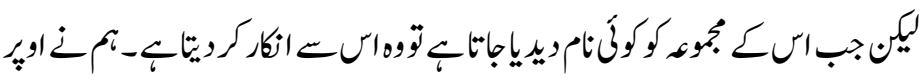

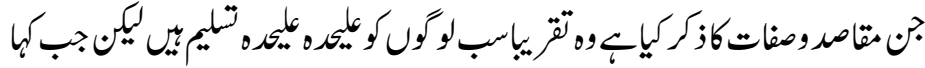

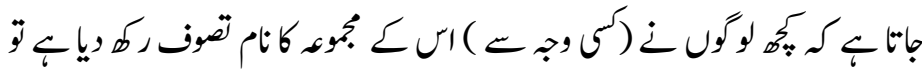

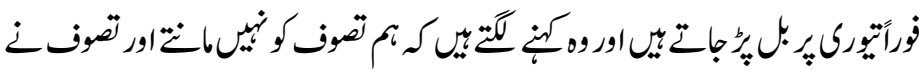

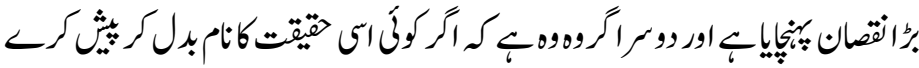

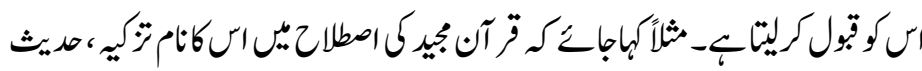

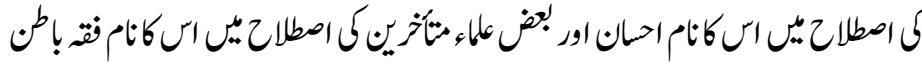

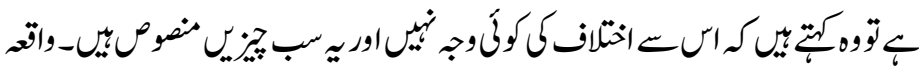

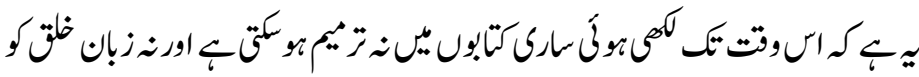

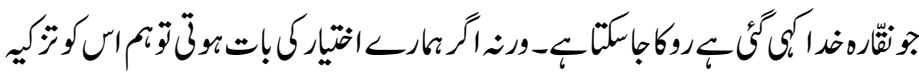

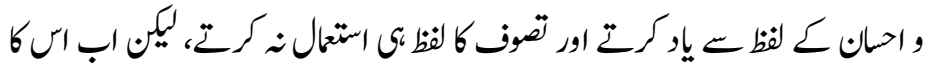

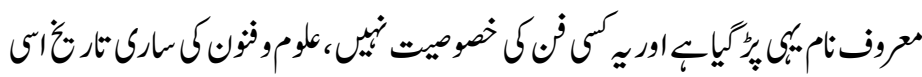

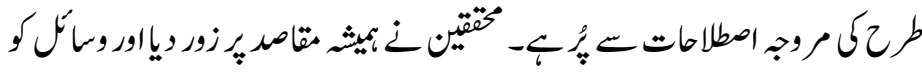

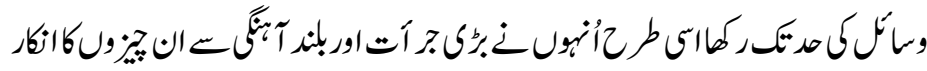

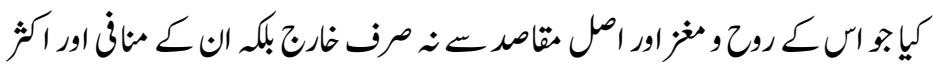

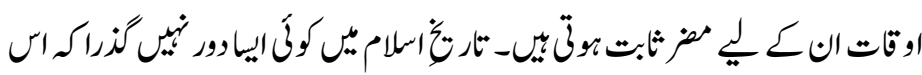

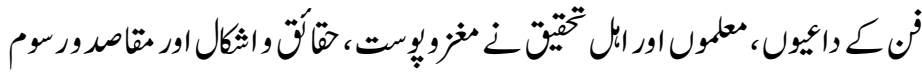

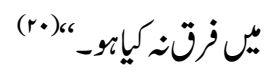

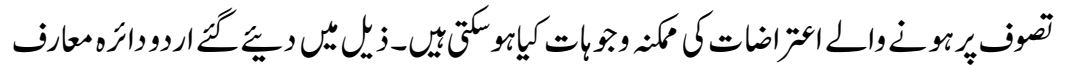

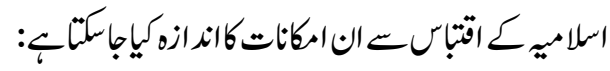


ISSN (Print): 2709-9636 | ISSN (Online): 2709-9644

Volume 2, 2021(Issue III, July to September)

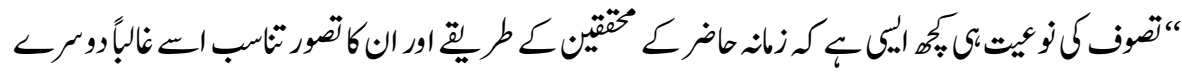

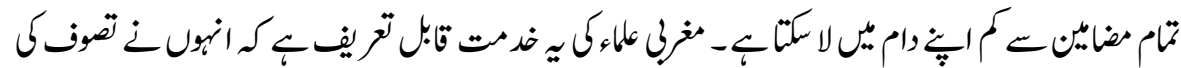

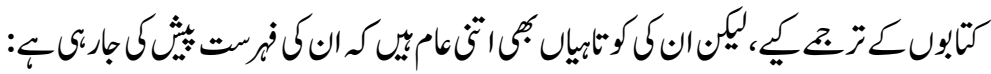

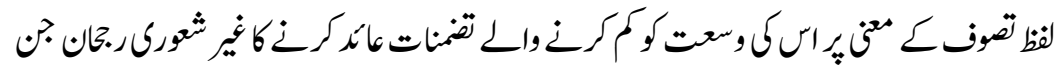

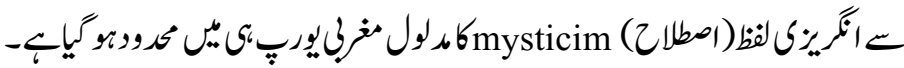

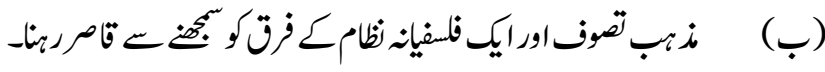

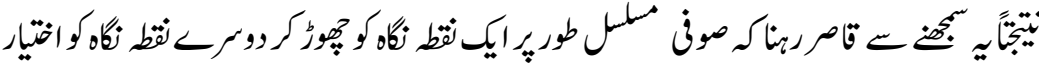

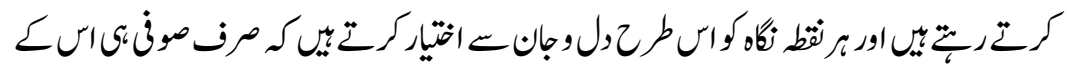

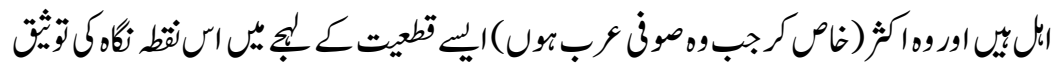

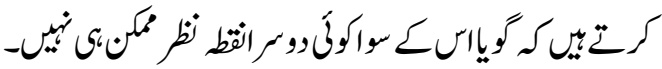

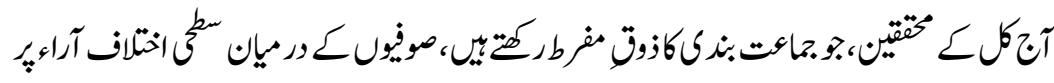

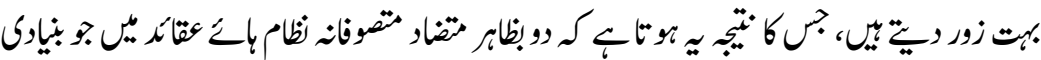

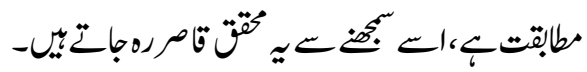

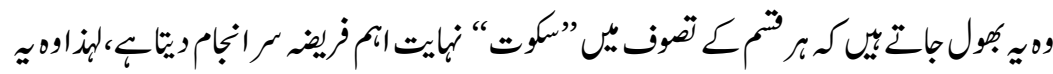

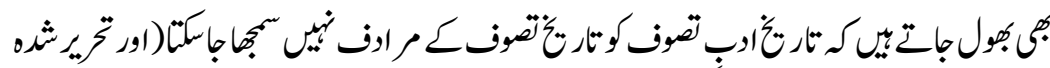

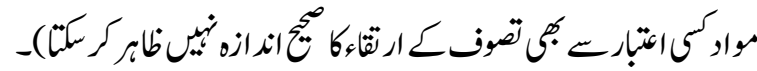

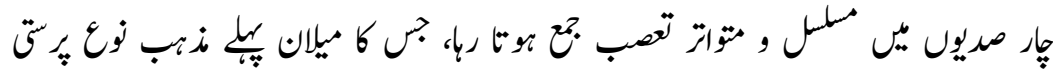

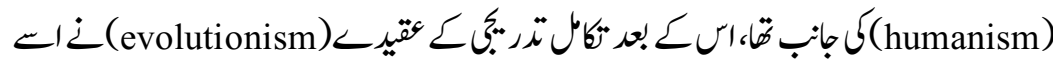

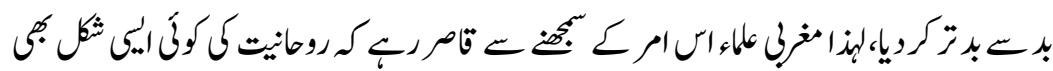

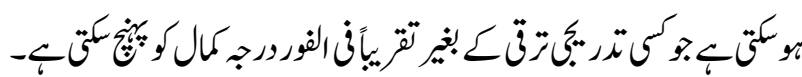

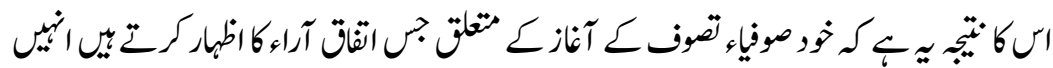

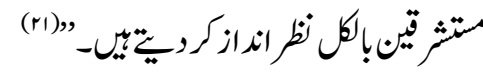




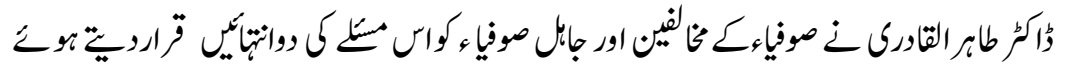

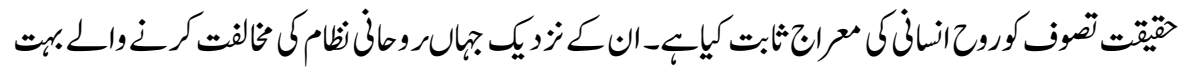

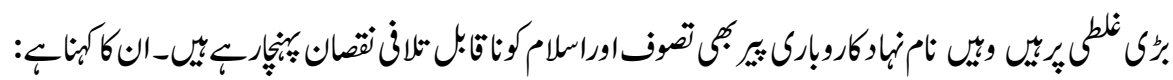

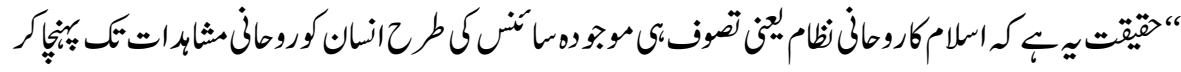

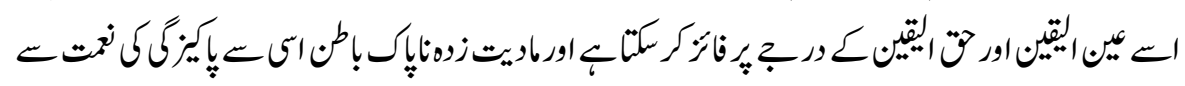

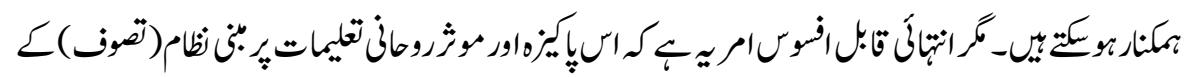

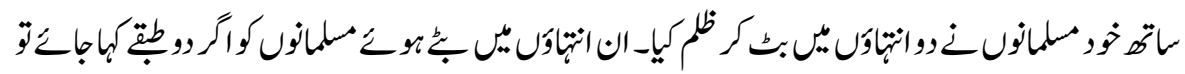
ان.

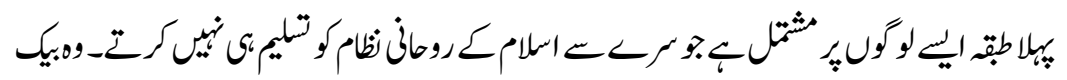

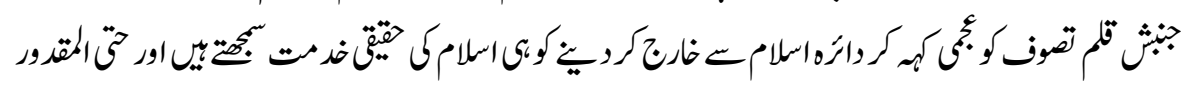

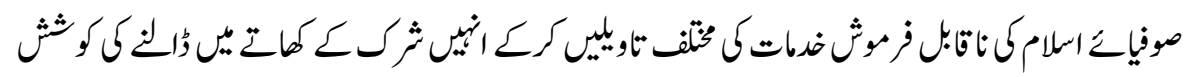

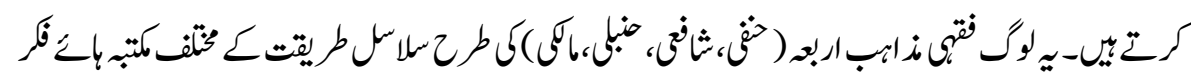

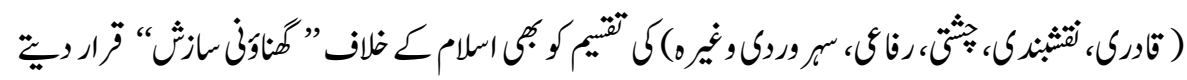

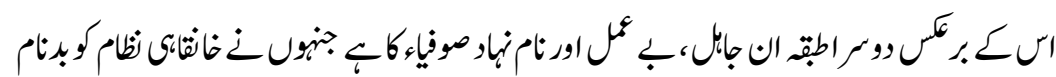

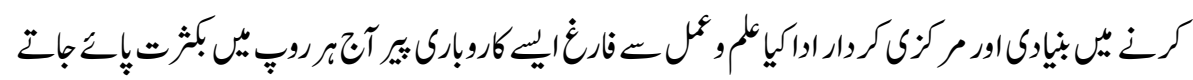

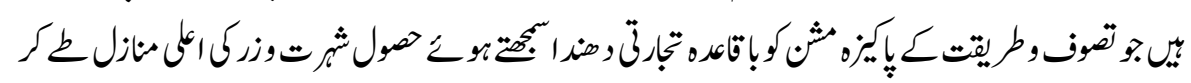

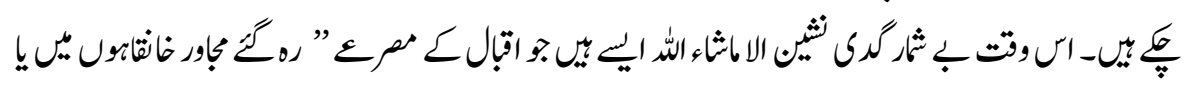

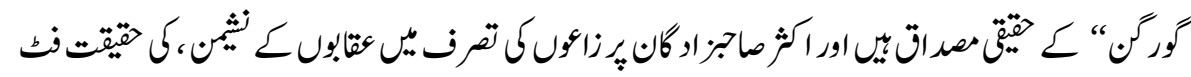

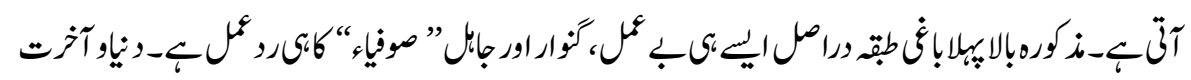

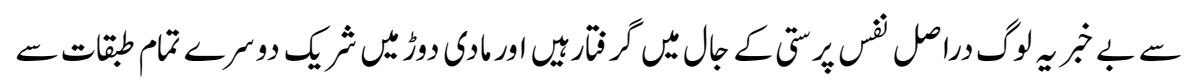

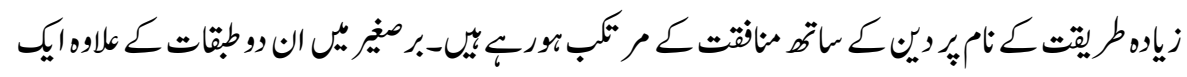

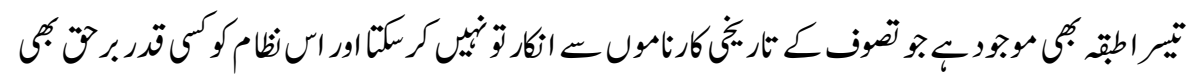


ISSN (Print): 2709-9636 | ISSN (Online): 2709-9644

Volume 2, 2021(Issue III, July to September)

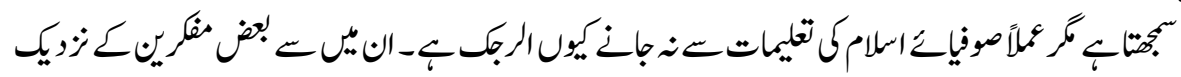

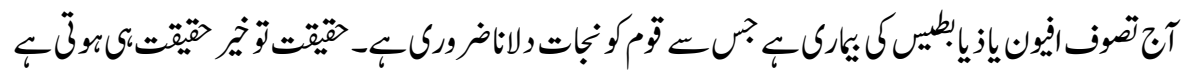

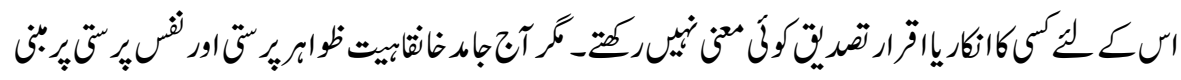

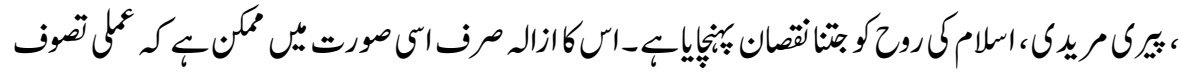

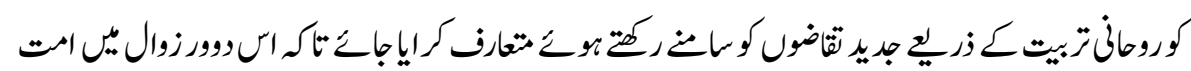

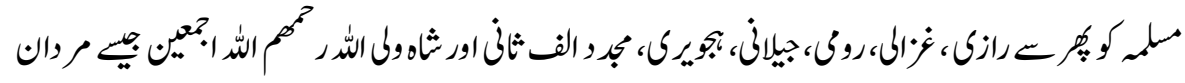

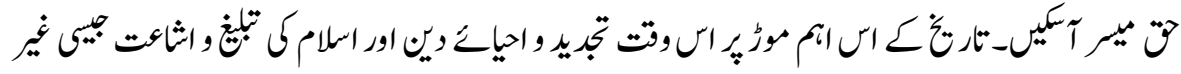

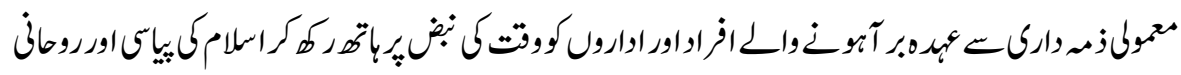

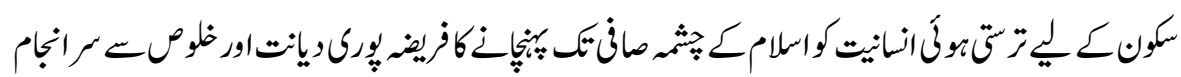
وينا جِابِ-")

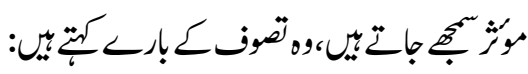

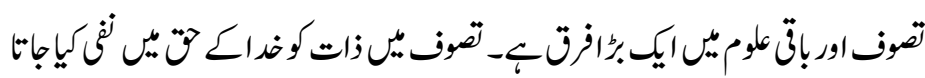

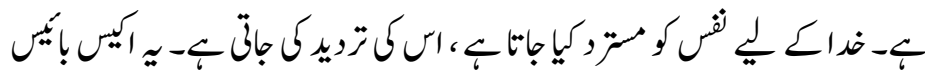

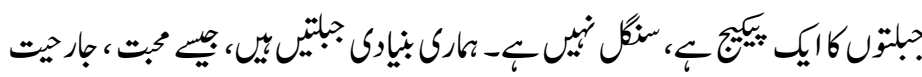

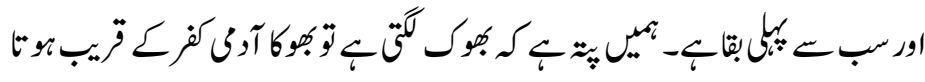

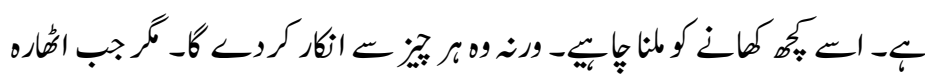

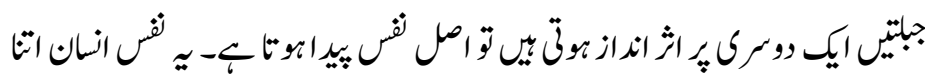

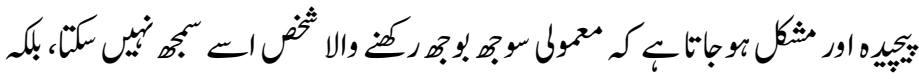

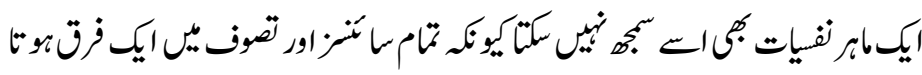

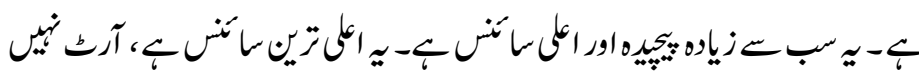

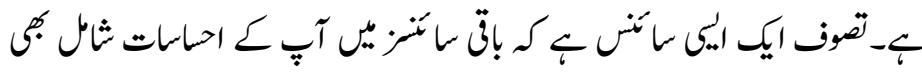

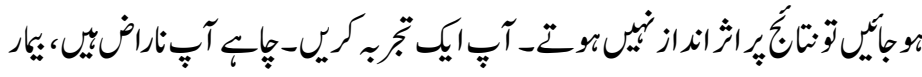

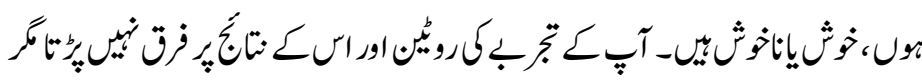




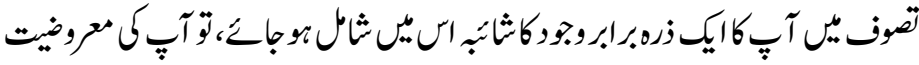

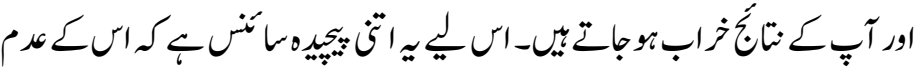

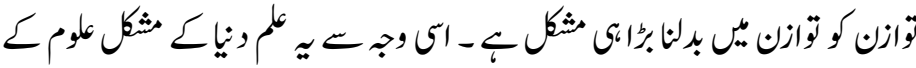

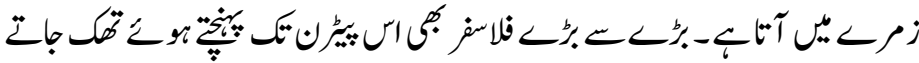

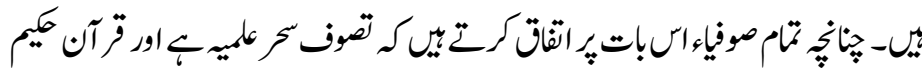

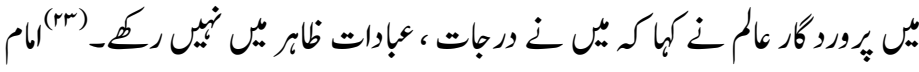

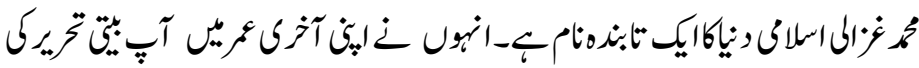

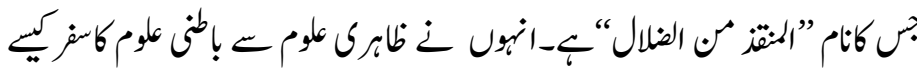

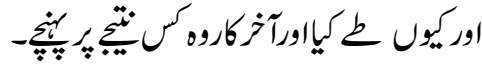

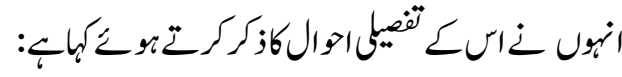

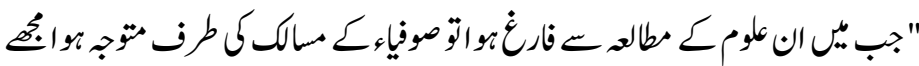

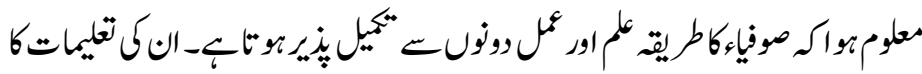

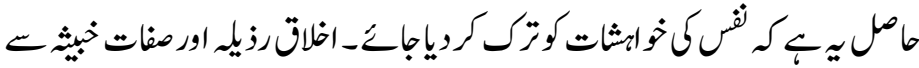

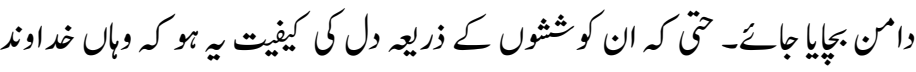

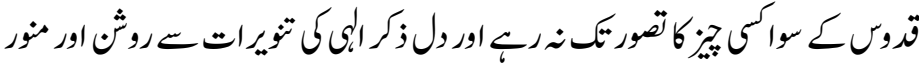

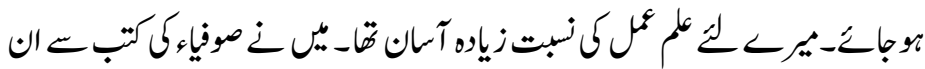

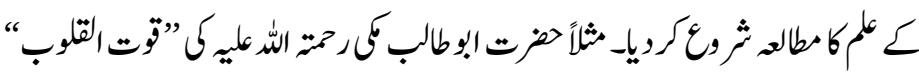

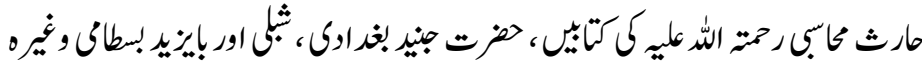

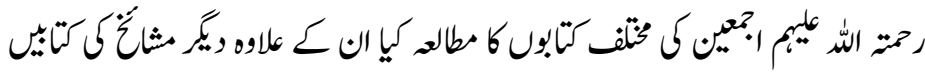

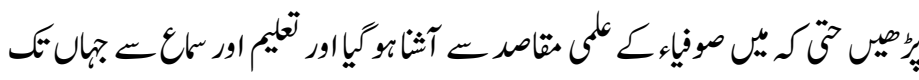

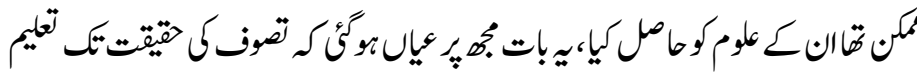

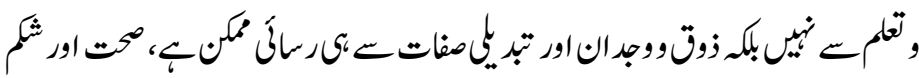

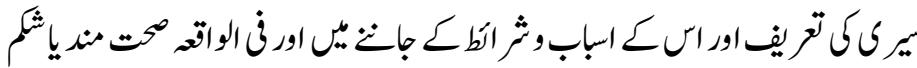


ISSN (Print): 2709-9636 | ISSN (Online): 2709-9644

Volume 2, 2021(Issue III, July to September)

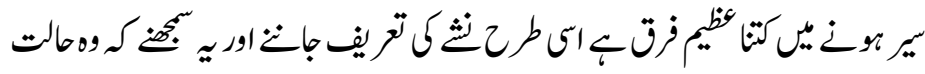

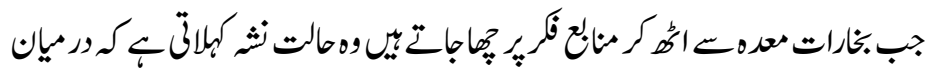

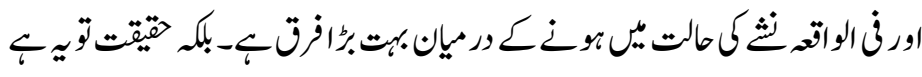

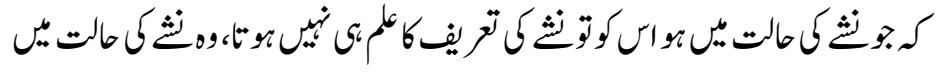

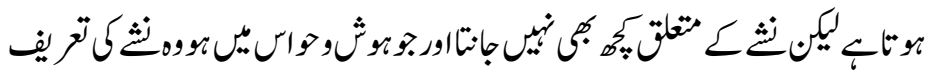

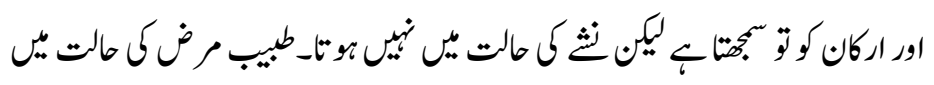

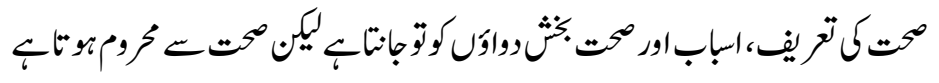

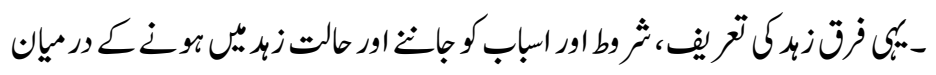

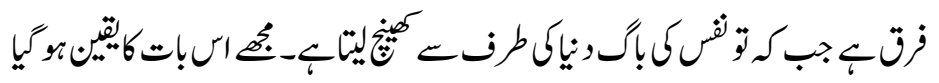

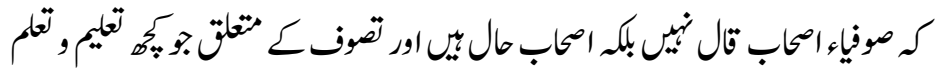

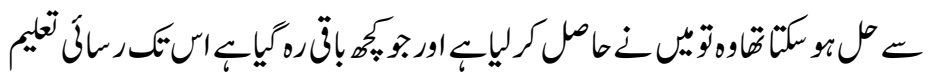

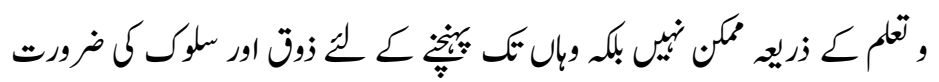

$(r)^{\prime \prime}-c_{6}$

نمانُكث

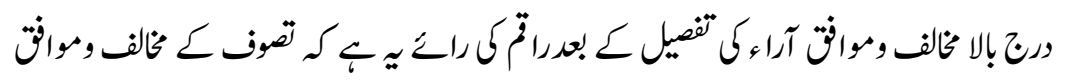

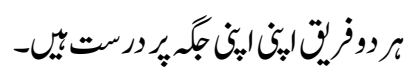

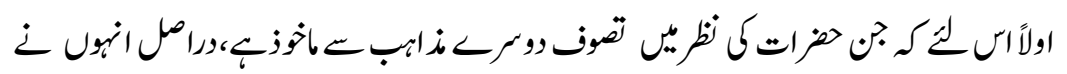

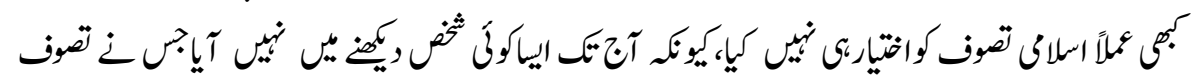

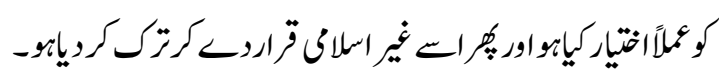

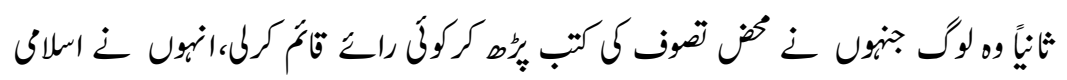

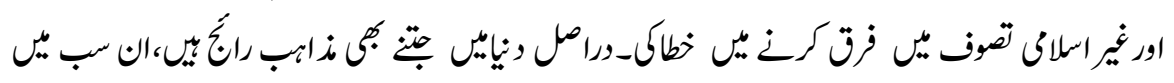

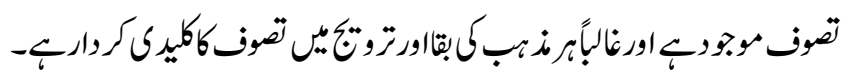


ISSN (Print): 2709-9636 | ISSN (Online): 2709-9644

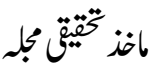

Volume 2, 2021(Issue III, July to September)

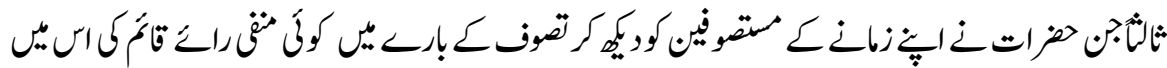

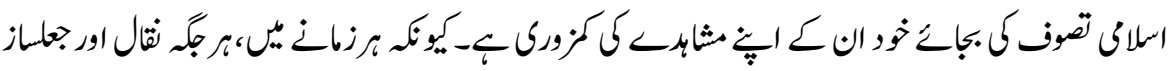

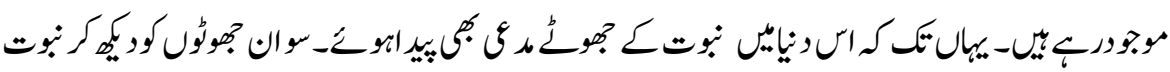

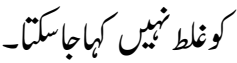

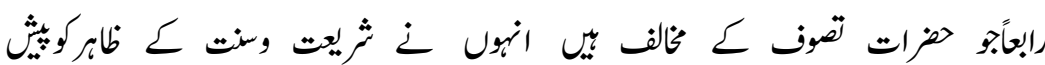

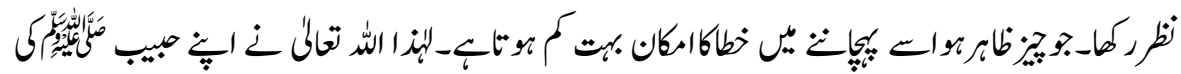

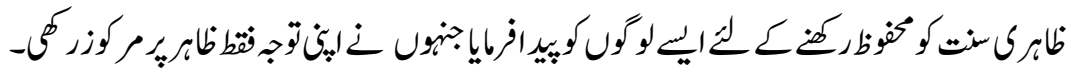

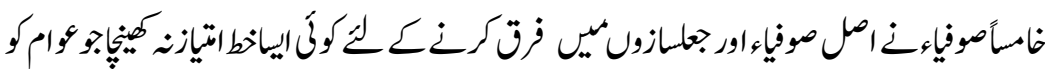

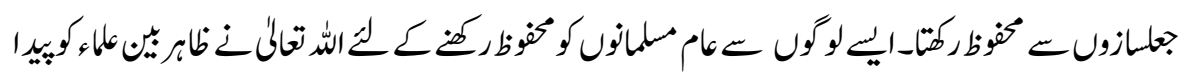

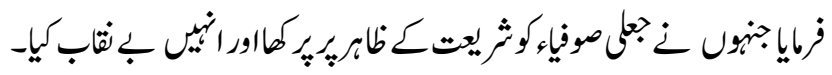

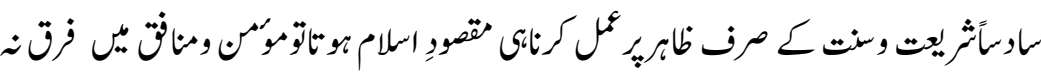

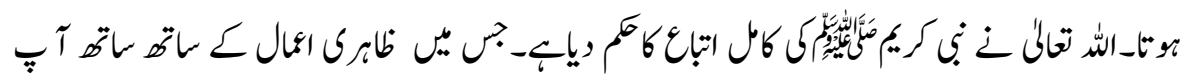

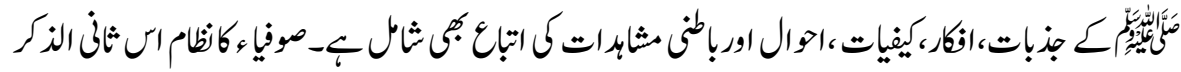

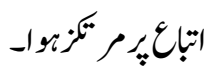

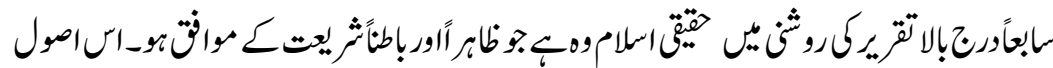

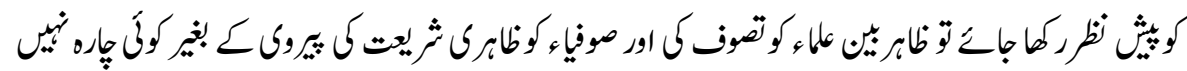
$-\frac{6}{6}$

$$
\text { حوالم جات }
$$

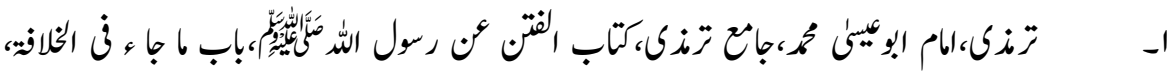

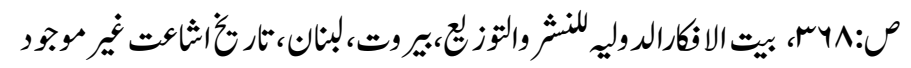

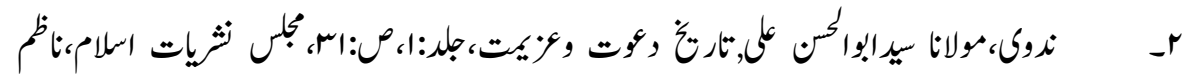

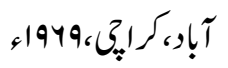




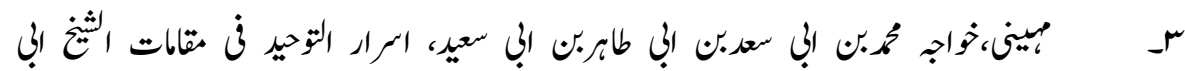

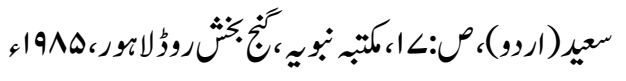

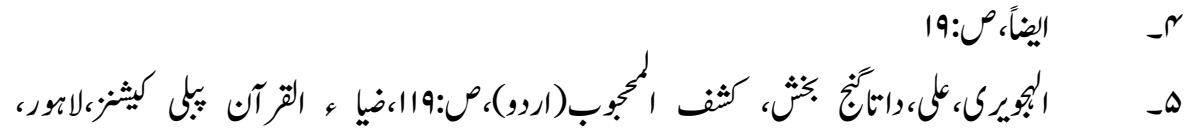

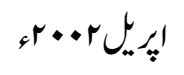$$
\text { - }
$$

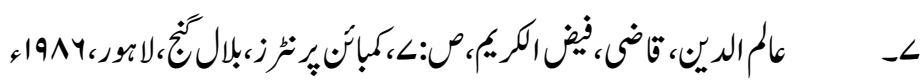

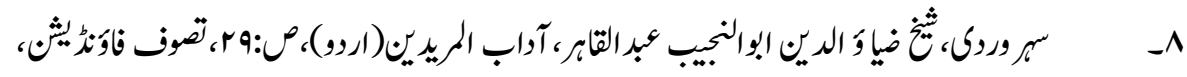

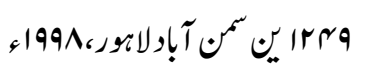

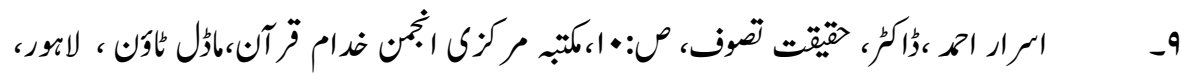

\section{جوركس..rاء}

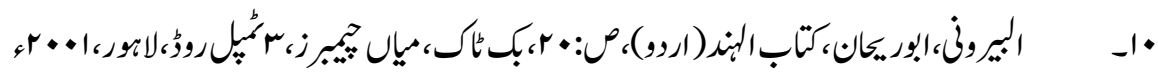

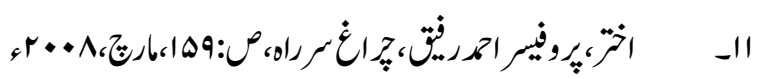

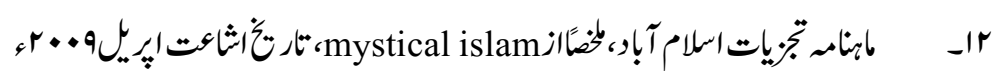

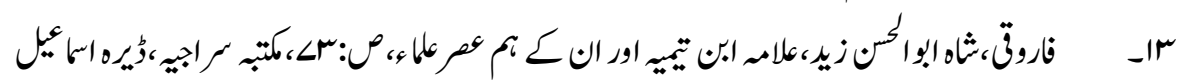

$$
\text { خان، 1914 }
$$

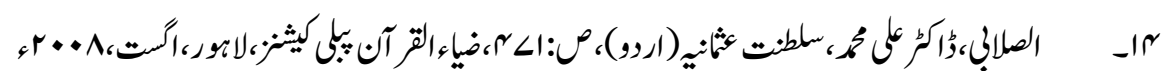

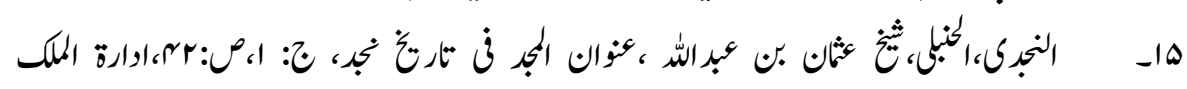

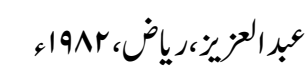

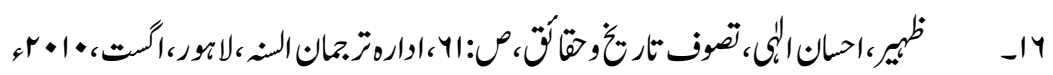

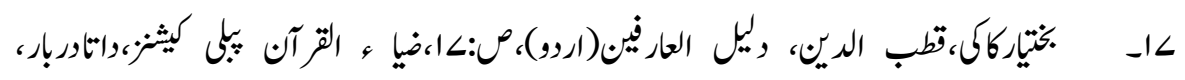

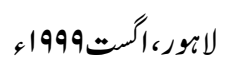


ISSN (Print): 2709-9636 | ISSN (Online): 2709-9644

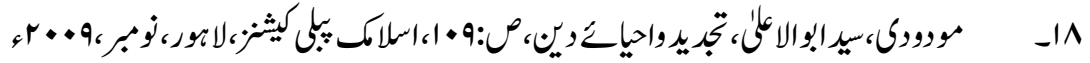

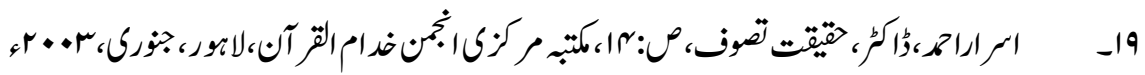

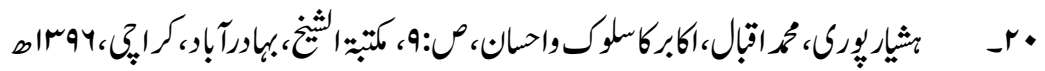

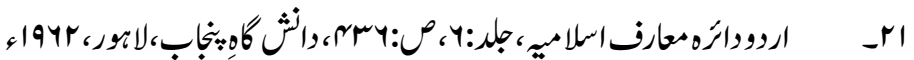

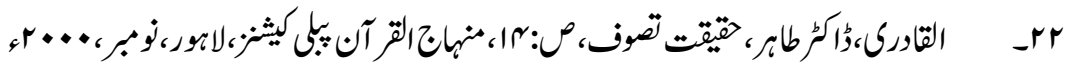

rr

rrr 